Article

\title{
Synthesis and Evaluation of Antileishmanial and Cytotoxic Activity of Benzothiopyrane Derivatives
}

\author{
Cristian Ortiz ${ }^{1}{ }^{\oplus}$, Fernando Echeverri $^{1} \oplus$, Sara Robledo ${ }^{2}{ }^{\oplus}$, Daniela Lanari ${ }^{3}$, Massimo Curini ${ }^{3}$, \\ Wiston Quiñones ${ }^{1, * \mathbb{D}}$ and Esteban Vargas ${ }^{1, *}$ \\ 1 Química Orgánica de Productos Naturales, Instituto de Química, Facultad de Ciencias Exactas y Naturales, \\ Universidad de Antioquia, calle 70, No. 52-21, Medellín A. A 1226, Columbia; \\ cristian.ortizb@udea.edu.co (C.O.); fernando.echeverri@udea.edu.co (F.E.) \\ 2 PECET-Facultad de Medicina, Universidad de Antioquia, calle 70 No. 52-21, Medellín A. A 1226, Columbia; \\ sara.robledo@udea.edu.co \\ 3 Dipartimento di Scienze Farmaceutiche, Università di Perugia, Via del Liceo, 1, 06123 Perugia, Italy; \\ daniela.lanari@unipg.it (D.L.); massimo.curini@unipg.it (M.C.) \\ * Correspondence: esteban.vargasc@udea.edu.co (E.V.); wiston.quinones@udea.edu.co (W.Q.); \\ Tel.: +5-742-196-596 (E.V. \& W.Q.)
}

Academic Editors: Andrew Tsotinis and Ioannis Papanastasiou

Received: 7 December 2019; Accepted: 30 January 2020; Published: 12 February 2020

check for updates

\begin{abstract}
In continuation of our efforts to identify promising antileishmanial agents based on the chroman scaffold, we synthesized several substituted $2 \mathrm{H}$-thiochroman derivatives, including thiochromenes, thichromanones and hydrazones substituted in C-2 or C-3 with carbonyl or carboxyl groups. Thirty-two compounds were thus obtained, characterized, and evaluated against intracellular amastigotes of Leishmania $(V)$ panamensis. Twelve compounds were active, with $\mathrm{EC}_{50}$ values lower than $40 \mu \mathrm{M}$, but only four compounds displayed the highest antileishmanial activity, with $\mathrm{EC}_{50}$ values below $10 \mu \mathrm{M}$; these all compounds possess a good Selectivity Index $>2.6$. Although two active compounds were thiochromenes, a clear structure-activity relationship was not detected since each active compound has a different substitution pattern.
\end{abstract}

Keywords: Leishmania; thiochromenes; benzothiopyrans; thiochroman-4-ones; synthesis; leishmaniasis; cytotoxicity

\section{Introduction}

Cutaneous leishmaniasis (CL) is a group of skin infections caused by intracellular protozoa belonging to the genus Leishmania and transmitted by Lutzomyia and Phlebotomus sand flies. CL is a poverty-associated disease considered by the World Health Organization as one of the 17 neglected diseases due to a lack of interest by the pharmaceutical industry to develop new drugs and a wide distribution around the world. More than 310 million people at risk, and about one million new cases are occurring annually. CL cases occur mainly in Afghanistan, Algeria, Brazil, Colombia, Iran, and Syria [1].

To date, a few drugs are available against leishmaniasis, including pentavalent antimonials, amphotericin B, and miltefosine. However, existing treatments are unsatisfactory because of their high cost, toxicity, need for prolonged treatment, and reduced efficacy, therefore, there is an urgent need to develop new molecules with novel modes of action against this disease.

The chroman (benzopyran) moiety is considered a privileged scaffold in medicinal chemistry since it exhibits a broad range of biological activities such as antiemetic, anti-hypertensive, anti-malarial, and insecticidal activities, among others [2-5]. From a bioisosteric point of view, replacement of the oxygen atom $(\mathrm{O})$ by a sulfur atom $(\mathrm{S})$ it may cause significant changes in the pharmacology activity since the 
changes in electron-donating potential and the size of sulfur cause solubility [6], polarity, hydrogen bonding and metabolism [7] modifications. In a previous paper, we have reported that acyl hydrazone derivatives of chromanone and thiochromanone have good in vivo antileishmanial activity with effective concentration $\left(\mathrm{EC}_{50}\right.$ ) values of 20.1 and $25.0 \mu \mathrm{M}$ respectively, in addition to anti-inflammatory and wound-healing properties [8]. Besides, acyl hydrazone derivatives of thiochroman-4-ones have been reported as potent inhibitors of cysteine proteases which has implications in the treatment of Chagas' disease [9,10]. A SAR study involving thiochroman-4-one derivatives found that compounds containing 1,1-dioxo-2-aryl-4H-thiochromen-4-one scaffolds displayed good antileishmanial activity below $10 \mu \mathrm{M}$. Ester and amide derivatives of thiochroman-4-ones were also include in this study; the amides tend to form intermolecular and intramolecular hydrogen bonds with other groups [11] and esters are used for masking polar moieties and taking advantage of the availability of endogenous, non-specific esterases, release the molecule inside the cell [12].

Herein, we report the synthesis of a library of compounds bearing a benzothiopyran moiety, including thiochromenes, thiochromanones and acyl hydrazones with a combination of fragments possessing a substituted carbonyl group in C-2 or C-3 and their in vitro anti-leishmanial and cytotoxic activities.

\section{Results}

\subsection{Synthesis, Dehydration and Oxidation of Thiochromanols}

In our search for methods for the synthesis of $2 \mathrm{H}$-thiochromene-like compounds, we first explored the synthetic methodologies used for their oxygenated counterparts. Several methodologies have been proposed, which include, among others, the Petasis reaction [13] of salicylaldehydes, tandem Michael additions [14], $\mathrm{PPh}_{3}$-catalyzed domino reactions [15] for the synthesis of chroman derivatives and the domino oxa-Michael aldol reaction [16]. The latter approach seemed likely to succeed with the mercapto counterpart.

Synthesis of the precursor 2-mercaptobenzaldehyde (mercaptosalicylaldehyde, Scheme 1) started from 2-chlorobenzaldehyde (1) and tert-butylthiol (2), following a modification of the Chemburkar procedure [17] using 1,5,7-triazabicyclo[4.4.0]dec-5-ene (TBD) under solvent-free conditions leading to high yields of the desired 2-(tert-butylthio)benzaldehyde (3). Treatment of 3 with a mixture of $\mathrm{HBr} /$ acetic acid in dimethyl sulfoxide (DMSO) gave the 2,2'-dithiodibenzaldehyde (4). Following the work of Humphrey and Hawkins [18], compound 4 was next allowed to react with $\mathrm{PPh}_{3}$ to give 2-mercaptobenzaldehyde (5), which readily oxidizes in air to give again disulfide 4.
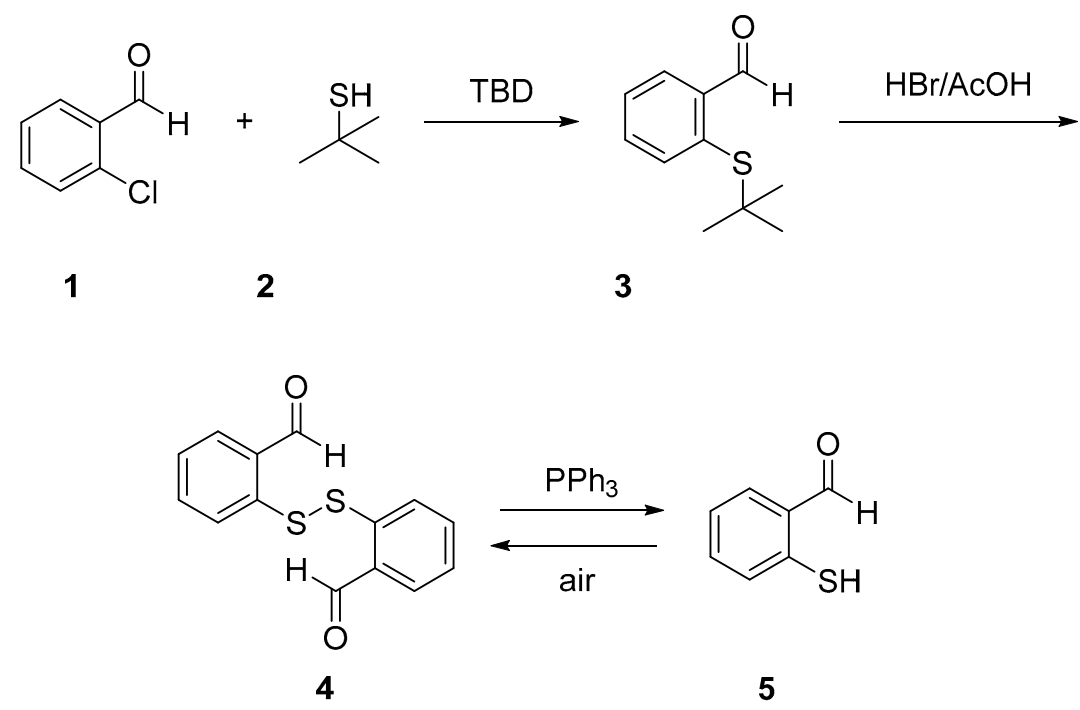

Scheme 1. Synthesis of 2-mercaptobenzaldehyde. 
Considering the tedious procedure to obtain $\mathbf{5}$ and its relatively easy oxidation in the presence of air, we decided to explore the synthesis of thiochromene compounds directly from aldehydes 3 or 4 . Thus, disulfide 4 was allowed to react with activated alkenes $6 \mathbf{a}-\mathbf{e}$ in the presence of 1,8-diazabicyclo[5.4.0]undec-7-ene (DBU) and triphenylphosphine, whereby thin layer chromatography (TLC) of the reaction mixture showed various spots with similar Rf values. ${ }^{1} \mathrm{H}-\mathrm{NMR}$ analysis of these crude mixtures revealed that this set of spots corresponds to the stereoisomers of thiochromanols $7 \mathbf{a}-\mathbf{e}$ (Scheme 2). Due to the difficulty in separating the mixture of stereoisomers and the inconvenience of using these mixtures in biological tests, we decided to use these compounds as a mixture in the following reactions. The reaction crude was passed through a chromatography column to remove the $\mathrm{DBU}$ and $\mathrm{PPh}_{3}$ and the excess of the starting materials.

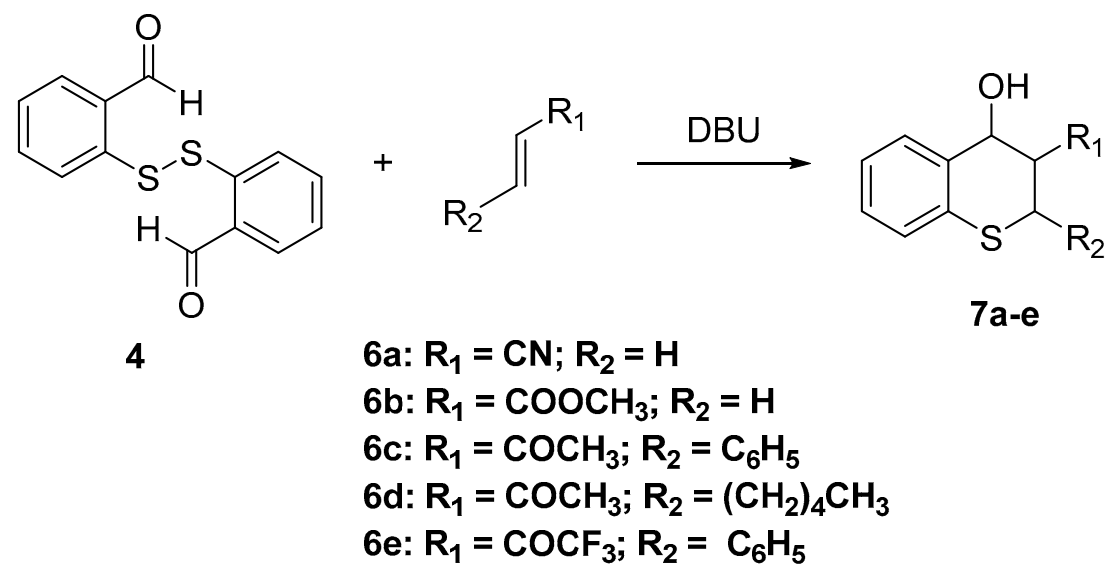

Scheme 2. Synthesis of $2 H$-thiochromanols derivatives $7 \mathbf{a}-\mathbf{e}$.

To obtain $2 \mathrm{H}$-thiochromenes $\mathbf{8 a - e}$ (Scheme 3), the mixtures of diastereomeric thiochromanols 7a-e were dehydrated by heating in the presence of acid (Amberlyst 15 or $\mathrm{HCl}$ ) or even by simple direct heating of the mixture containing the $\mathrm{DBU}$ and $\mathrm{PPh}_{3}$.

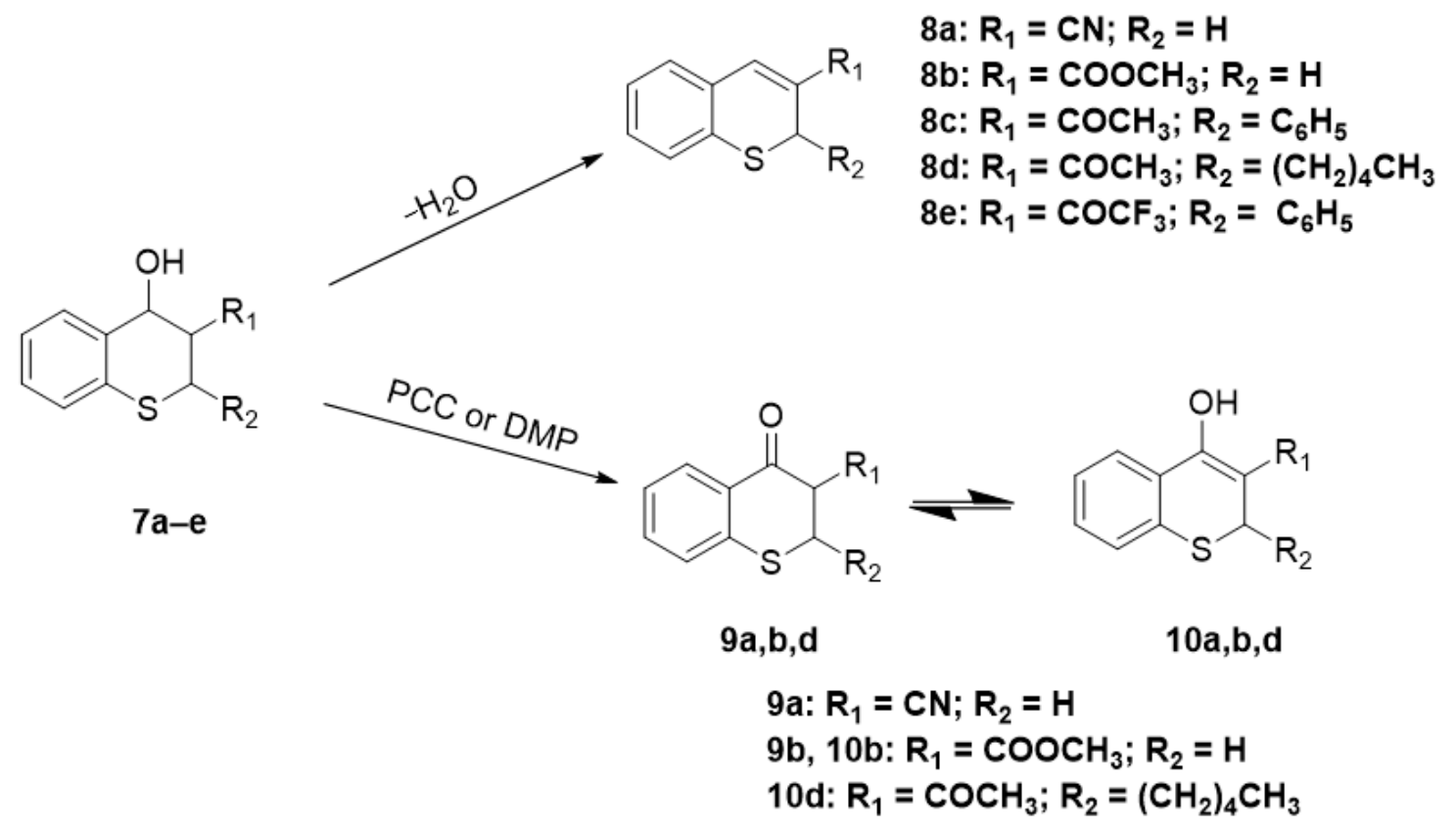

Scheme 3. Synthesis of $2 H$-thiochromenes $\mathbf{8 a}-\mathbf{e}$, ketones $\mathbf{9 a}, \mathbf{b}, \mathbf{d}$ and the enol forms $\mathbf{1 0 a}, \mathbf{b}, \mathbf{d}$. 
In the search for compounds bearing a thiochroman-4-one moiety, thiochromanols 7a-e were treated with oxidants like pyridinium chlorochromate (PCC) or Dess-Martin Periodinane reagent (DMP, Scheme 3). Oxidation of 7c and 7e did not give the expected products. On the other hand, compounds $\mathbf{7 a}, \mathbf{b}, \mathbf{d}$ gave oxidation products which could tautomerize and were analyzed by NMR to determine in which tautomeric form they exist.

NMR spectra of the oxidation product of 7a showed only one set of signals in which the protons at $\delta 4.18(\mathrm{dd}, J=11.6,3.7 \mathrm{~Hz}, 1 \mathrm{H}), 3.67(\mathrm{dd}, J=13.5,11.7 \mathrm{~Hz}, 1 \mathrm{H})$ and $3.57-3.40(\mathrm{~m}, 1 \mathrm{H})$ and the ${ }^{13} \mathrm{C}-$ NMR $\delta 184.6$ characteristic of a ketone group indicate that the compound exists only as its keto form $9 \mathbf{a}$.

In the case of the oxidation of $\mathbf{7 b}$, the NMR spectra showed two sets of signals, indicating the existence of two tautomeric forms. In the keto form $\mathbf{9 b}$, proton $\mathrm{H} 5$ appears as a doublet at $8.17 \mathrm{ppm}$, $J=7.9 \mathrm{~Hz}$, while in the enol form $\mathbf{1 0 b}$ this proton signal is shifted at $7.89, \mathrm{~d}, J=7.7 \mathrm{~Hz}$, both signals integrating for 0.2 and 1.0, respectively, the same ratio was can be calculated with the protons of the methoxy group of the ester. A calculation of peak-intensity showed that this tautomeric mixture consisted of $83 \%$ of the enol form and $17 \%$ of the keto form.

A similar analysis for the oxidation $7 \mathbf{d}$ showed no proton at $\mathrm{C} 3$, and the ${ }^{13} \mathrm{C}-\mathrm{NMR}$ resonance at $\delta 195.4$ and 174.0 is not consistent with a diketo compound $\mathbf{9 d}$, which indicates that it exists only as an enol compound 10d. It can be assumed that this enol form was stabilized by the intramolecular hydrogen bond.

\subsection{Alternative Synthesis of $2 H$-Thiochromene Compounds}

Taking into account that S-tert-butyl groups are cleaved under acidic conditions [19,20], treatment of compound 3 with hydrochloric acid $(\mathrm{HCl})$ or $p$-toluenesulfonic acid (PTSA) gave a dimeric hemithioacetal 11 (Scheme 4), previously reported by Dickmann [21]. Formation of compound 11 must happen through the formation of 2-mercaptobenzaldehyde (5), followed by dimerization.

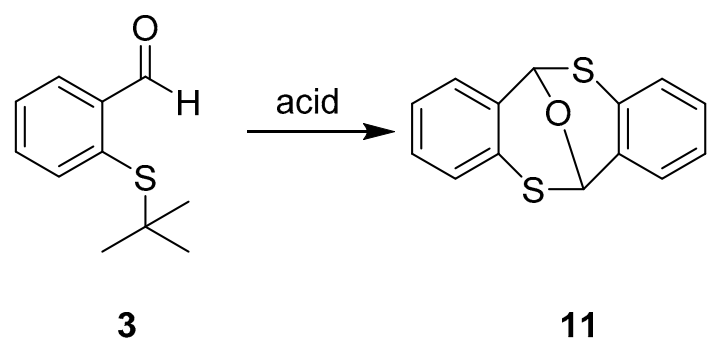

Scheme 4. Proposed structure of the dimeric hemithioacetal 11.

The above results led us to think that compound 5 formed in situ could react with suitably activated alkenes to yield the addition product; thus, we carried out the reaction of 3 in the presence of cinnamaldehydes 12a-d using $12 \mathrm{M} \mathrm{HCl}$. Thus, substituted 2-phenyl-2H-thiochromene-3-carbaldehydes 13a-d in moderate to good yields were effectively produced (Scheme 5).

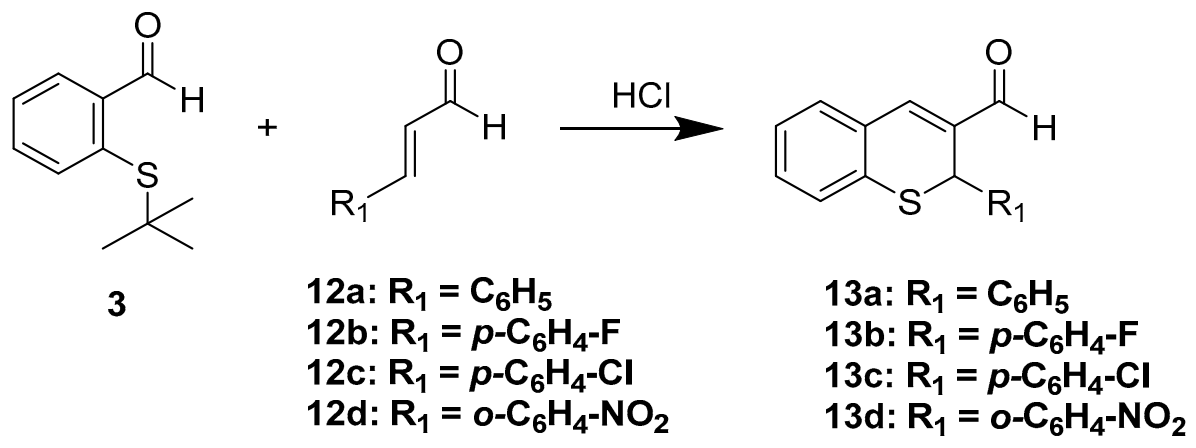

Scheme 5. Direct synthesis of $2 H$-thiochromenes starting from 3 and cinnamic aldehydes. 
Similarly, trans-chalcone reacted with 3 in the presence of 4-toluenesulfonic acid in toluene to give phenyl-(2-phenyl-2H-thiochromen-3-yl)-methanone (15a) in 46\% yield (Scheme 6). Acid-catalyzed in situ formation of the chalcones followed by reaction with 2-(tert-butylthio)-benzaldehyde in a one-pot procedure also resulted in the formation of the desired aryl-2H-thiochromen-methanones $\mathbf{1 5 b} \mathbf{b}$.<smiles>Cc1cccc(C)c1</smiles>

3<smiles>CC(C)(C)Sc1ccccc1C=O</smiles>

3
14<smiles>[R]c1ccc(C(C)=O)cc1</smiles>

16a: $R_{1}=H$

16b: $\mathrm{R}_{1}=\mathrm{Cl}$;

16c: $\mathrm{R}_{\mathbf{1}}=\mathrm{Cl}$;<smiles>[R2]c1ccc(C=O)cc1</smiles>

17a: $R_{1}=H$

17b: $R_{1}=C F_{3}$

17c: $\mathrm{R}_{1}=\mathrm{NO}_{2}$<smiles>[R]c1ccc(C(=O)C2=Cc3ccccc3SC2c2ccc([R2])cc2)cc1</smiles>

15a: $R_{1}=H ; R_{2}=H$

15b: $R_{1}=\mathrm{Cl} ; \mathrm{R}_{2}=\mathrm{CF}_{3}$

15c: $\mathrm{R}_{1}=\mathrm{Cl} ; \mathrm{R}_{2}=\mathrm{NO}_{2}$

Scheme 6. Synthesis of (aryl-2H-thiochromen-3-yl)-methanones from chalcones.

\subsection{Synthesis of 4-oxo-thiochroman-2-Carboxylic Acid and Its Derivatives}

Derivatives of thiochroman-4-one are typically prepared by conjugate additions of thiophenols to $\alpha, \beta$-unsaturated carboxylic acids followed by treatment with a strong dehydrating agent or by formation of the corresponding acid chlorides followed by treatment with a Lewis acid like $\mathrm{AlCl}_{3}$ or $\mathrm{SnCl}_{4}$. Similarly 4-oxo-thiochroman-2-carboxylic acids 20a-d were obtained by reacting thiophenols 18a-d with furan-2,5-dione (maleic anhydride, 19) in the presence of triethylamine and with subsequent treatment with $\mathrm{AlCl}_{3}$ (Scheme 7).<smiles>[R]c1ccc(S)cc1[R]</smiles>

18a: $R_{1}=H ; R_{2}=H$

18b: $R_{1}=F ; R_{2}=H$

18c: $\mathrm{R}_{\mathbf{1}}=\mathrm{OCH}_{3} ; \mathrm{R}_{\mathbf{2}}=\mathrm{H}$

18d: $R_{1}=H ; R_{2}=O \mathrm{CH}_{3}$<smiles>O=C1C=CC(=O)O1</smiles><smiles>CCCCCNCC</smiles>

19

Scheme 7. Synthesis of 4-oxothiochroman-2-carboxylic acid.

In order to get a set of compounds that allow us to perform a SAR analysis to establish the influence of the functional groups and the length of the side chains we prepared a set of esters and amides of 4-oxo-thiochroman-2-carboxylic acids. 
Esters of 4-oxo-thiochroman-2-carboxylic acid 22a were prepared by reaction with the corresponding alcohols $\mathbf{2 1 a}-\mathbf{d}$ using dicyclohexylcarbodiimide (DCC) as a coupling agent and 4-dimethylaminopyridine (DMAP) as a catalyst (Scheme 8).<smiles>O=C1CC(C(=O)O)Sc2ccccc21</smiles>

$20 a$<smiles>CC(C)(C)C(C)(C)O</smiles>

21a: $n=1$

21b: $n=3$

21c: $n=5$

21d: $n=9$

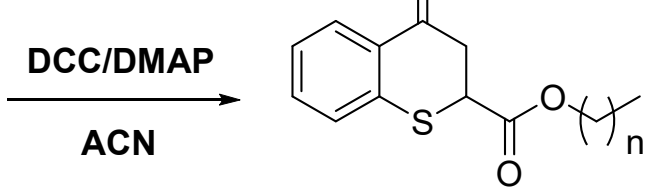
22a: $n=1$
$22 b: n=3$
22c: $n=5$
22d: $n=9$

Scheme 8. Esters of 4-oxo-thiochroman-2-carboxylic acid.

Amides 24a-c were prepared by reacting the corresponding amines 23a-c with 4-oxo-thiochroman-2-carboxylic acid 20a under Schotten-Baumann conditions (Scheme 9) using a biphasic system containing in the organic layer, oxalyl chloride $(\mathrm{COCl})_{2}$ and dimethyl formamide as catalyst (DMF) and aqueous sodium hydroxide.

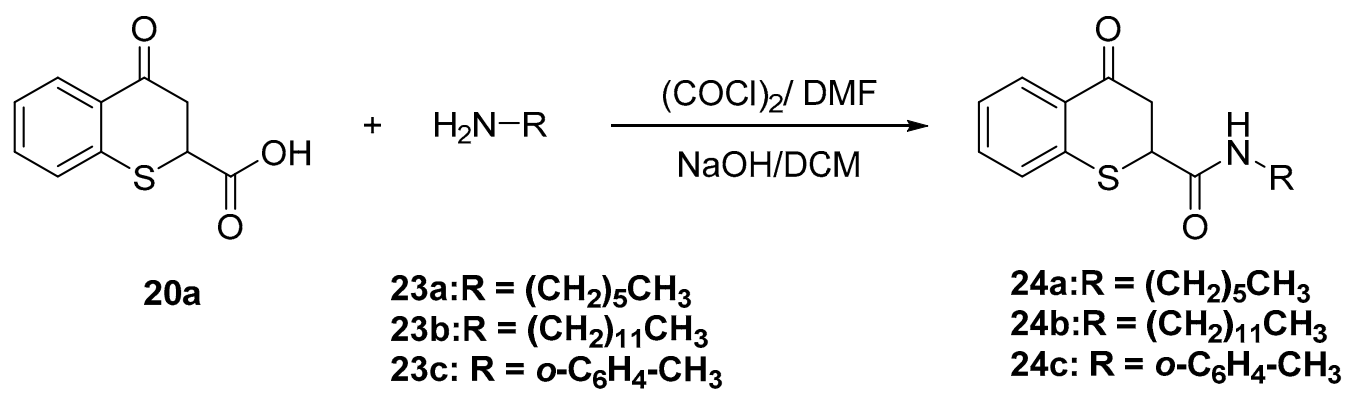

Scheme 9. Synthesis of amides of 4-oxo-thiochroman-2-carboxylic acid.

\subsection{Synthesis of Acyl Hydrazone Derivatives}

As it was mentioned before, compounds having an acyl hydrazone moiety have shown good antiparasitic activities. According to this we decided to prepare some derivatives with this structural feature. Acyl hydrazone derivatives 26a-c were prepared by reaction of ethyl 4-oxothiochromane-2-carboxylate with acyl hydrazides $25 \mathbf{a}-\mathbf{c}$ in the presence of acetic acid (Scheme 10).<smiles>CCOC(=O)C1CC(=O)c2ccccc2S1</smiles><smiles>[R]C(=O)NN</smiles>

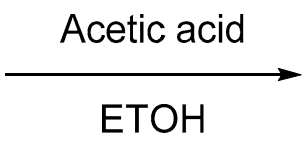

\section{2a}

$$
\begin{aligned}
& \text { 25a: } R=\mathrm{C}_{6} \mathrm{H}_{5} \\
& \text { 25b: } R=\mathrm{C}_{5} \mathrm{NH}_{4} \\
& \text { 25c: } R=\mathrm{CONH}_{2}
\end{aligned}
$$<smiles>[R]C(=O)N/N=C1\CC(C(=O)OCC)Sc2ccccc21</smiles> 


\subsection{Resolution of Enantiomers of 4-oxo-thiochroman-2-carboxylic Acid Using Brucine}

To establish the difference in antileishmanial activity of the enantiomers of 4-oxo-thiochroman-2-carboxylic acid (20a) we attempted the chiral resolution by diastereomeric salt formation through reaction with optically pure (-) -brucine 27 as a chiral selector (Scheme 11). Thus, 20a was allowed to react with (-) -brucine 27 in a mixture of THF/water 4:1 at room temperature overnight, to yield a mixture of diastereomeric salts. Attempts were made to crystallize the mixture by slow evaporation of different solvents (acetone, THF, water, ethanol and ethyl acetate). Finally, crystalline salts were obtained after evaporation of ethyl acetate. Crystals were separated from mother liquors and were subjected to acid hydrolysis to yield the salt of $(-)$ - brucine and an enantiomerically enriched sample of 4-oxo-thiochroman-2-carboxylic acid (+)-20a with specific rotation $[\alpha]^{25}=+35.6$. After evaporating the ethyl acetate from mother liquors, we obtained an enriched sample of the less crystalline diastereoisomeric salt. Acid hydrolysis of the residue of the mother liquors yield a mixture of enantiomers with specific rotation of $[\alpha]^{25} \mathrm{D}=-10.8$ for $(-)-20 a$. We did not determine absolute configuration nor enantiomeric excess.

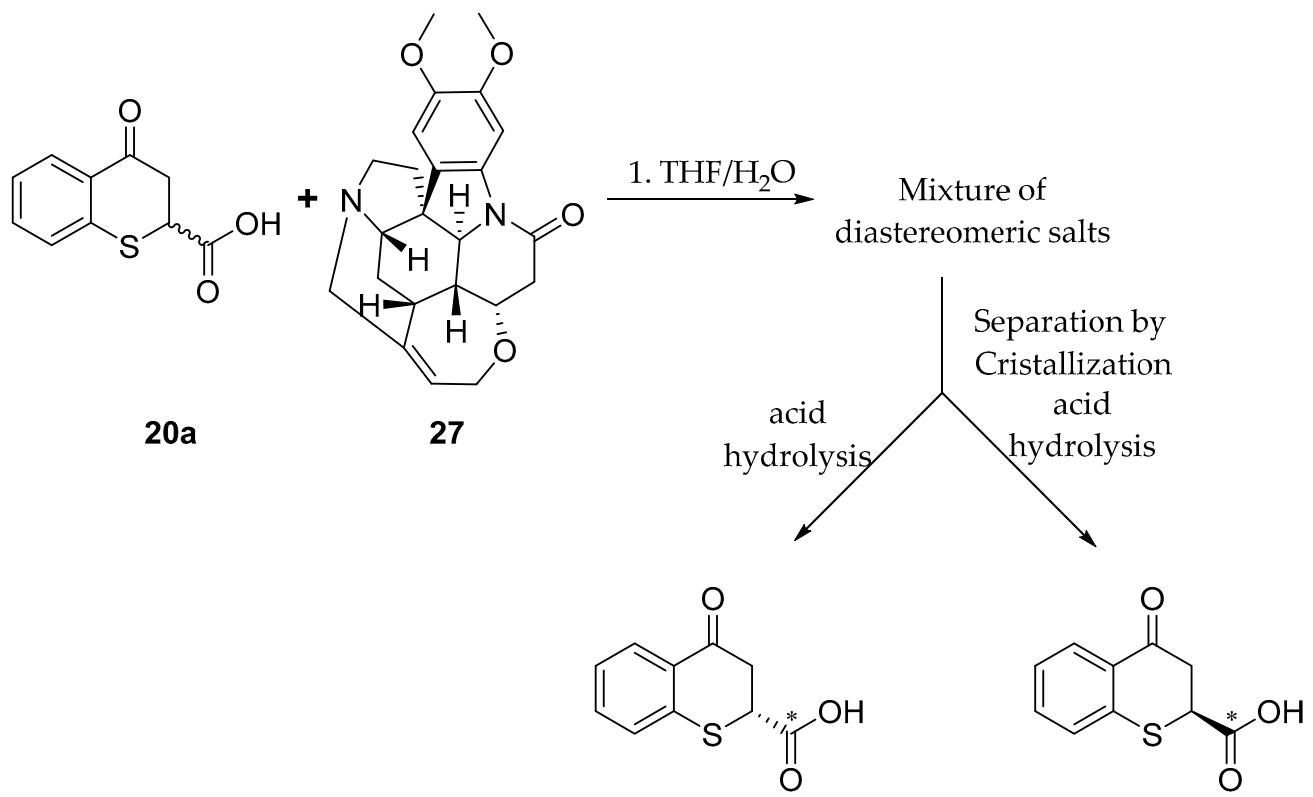

Scheme 11. Chiral resolution of 4-oxothiochroman-2-carboxylic acid 20a.

Enantiomerically enriched samples of butyl 4-oxothiochromane-2-carboxylates (+)-22b with $[\alpha]_{\mathrm{D}}^{25}=+32.4$ and $(-)^{-22} \mathbf{b}[\alpha]_{\mathrm{D}}^{25}=-8.3$, respectively, were obtained by reaction of butanol with enantiomerically enriched samples of 4-oxo-thiochroman-2-carboxylic acid (+)-20a or (-)-20a (Scheme 12).<smiles>O=C1CC(C(=O)O)Sc2ccccc21</smiles>

$20 \mathrm{a}(+)$ or $20 \mathrm{a}(-)$

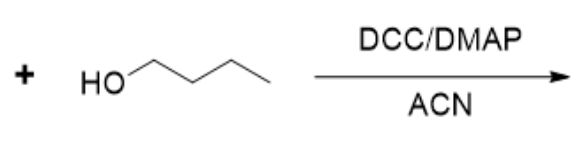

$$
\begin{gathered}
22 b(+) ;[a]^{25}=+32.4 \\
\text { or } \\
22 b(-) ;[a]^{25}=-8.3
\end{gathered}
$$

Scheme 12. Enantiomerically enriched butyl 4-oxothiochromane-2-carboxylates. 


\subsection{Antileishmanial and Cytotoxic Activities}

The synthesized compounds were evaluated for their in vitro antileishmanial and cytotoxic activities (Table 1), following the methods of Pulido et al. [22] Amphotericin B, with $\mathrm{EC}_{50}$ and $\mathrm{LC}_{50}$ values of $0.05 \mu \mathrm{M}$ and $56.8 \mu \mathrm{M}$, respectively, was used as a control.

Table 1. In vitro antileishmanial and cytotoxic activities.

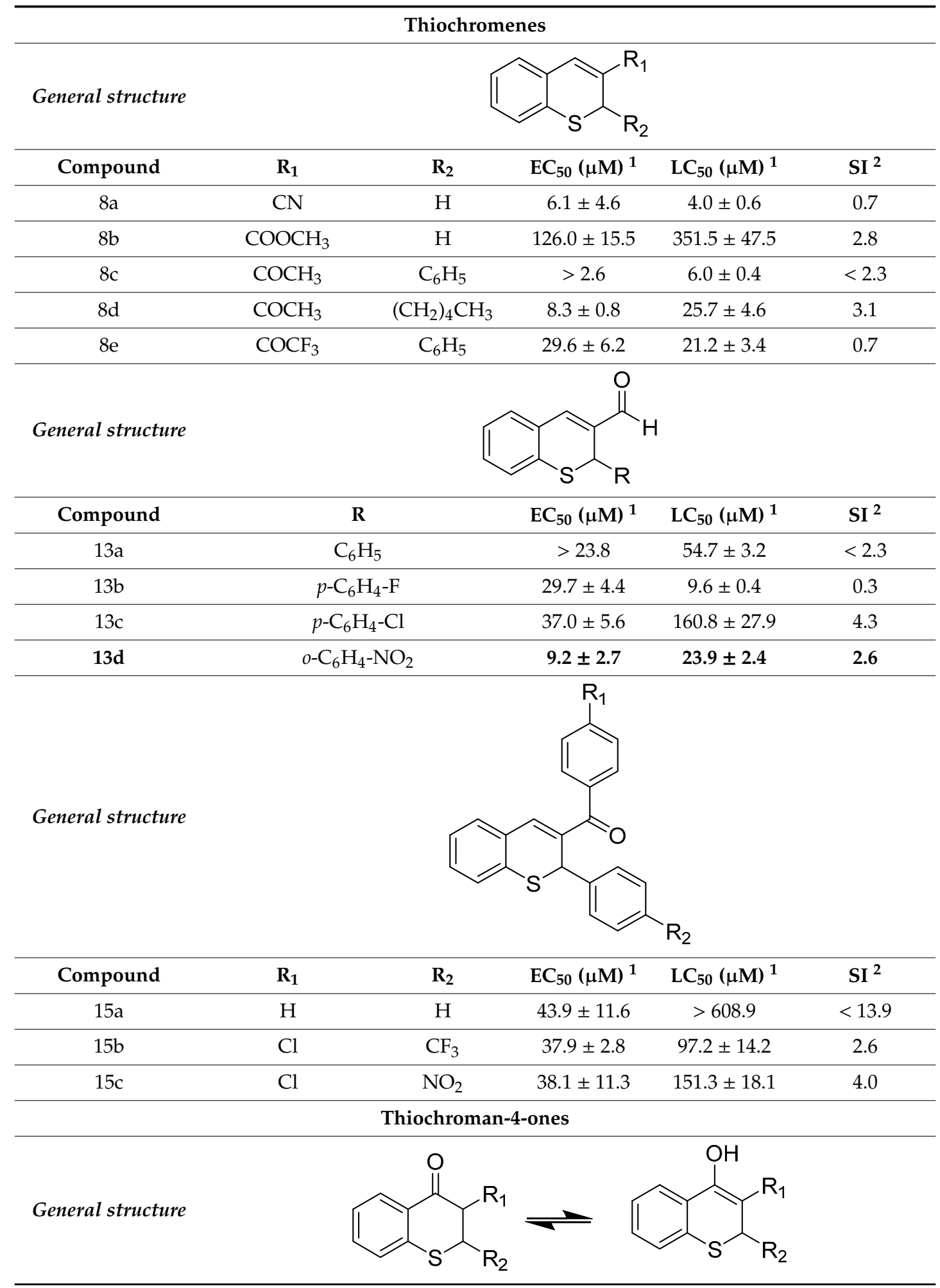


Table 1. Cont.

\begin{tabular}{|c|c|c|c|c|c|}
\hline \multicolumn{6}{|c|}{ Thiochromenes } \\
\hline Compound & $\mathbf{R}_{1}$ & $\mathbf{R}_{2}$ & $\mathrm{EC}_{50}(\mu \mathrm{M})^{1}$ & $\mathrm{LC}_{50}(\mu \mathrm{M})^{1}$ & $\mathrm{SI}^{2}$ \\
\hline $9 a$ & $\mathrm{CN}$ & $\mathrm{H}$ & $107.7 \pm 34.3$ & $770.5 \pm 49.7$ & 7.2 \\
\hline $9 b+10 b$ & $\mathrm{COOCH}_{3}$ & $\mathrm{H}$ & $133.6 \pm 27.0$ & $485.0 \pm 45.4$ & 3.6 \\
\hline $10 \mathrm{~d}$ & $\mathrm{COCH}_{3}$ & $\left(\mathrm{CH}_{2}\right)_{4} \mathrm{CH}_{3}$ & $12.5 \pm 3.3$ & $51.0 \pm 9.0$ & 4.1 \\
\hline \multicolumn{6}{|l|}{ General structure } \\
\hline Compound & $\mathbf{R}_{2}$ & $\mathbf{R}_{3}$ & $\mathrm{EC}_{50}(\mu \mathrm{M})^{1}$ & $\mathrm{LC}_{50}(\mu \mathrm{M})^{1}$ & $\mathrm{SI}^{2}$ \\
\hline $20 a$ & $\mathrm{H}$ & $\mathrm{OH}$ & $414.1 \pm 58.5$ & $132.8 \pm 67.7$ & 0.3 \\
\hline $20 \mathrm{~b}$ & $\mathrm{H}$ & $\mathrm{OH}$ & $\begin{array}{c}3517.1 \pm \\
3007.5\end{array}$ & $210.1 \pm 78.7$ & 0.1 \\
\hline $20 c$ & $\mathrm{OCH}_{3} \quad \mathrm{H}$ & $\mathrm{OH}$ & $493.6 \pm 324.4$ & $76.3 \pm 8.6$ & 0.2 \\
\hline $20 d$ & $\mathrm{H} \quad \mathrm{OCH}_{3}$ & $\mathrm{OH}$ & $277.0 \pm 100.9$ & $90.4 \pm 16.4$ & 0.3 \\
\hline $22 \mathrm{a}$ & $\mathrm{H}$ & $\mathrm{OCH}_{2} \mathrm{CH}_{3}$ & $>68.5$ & $211.1 \pm 0.7$ & $<3.1$ \\
\hline $22 \mathrm{~b}$ & $\mathrm{H}$ & $\mathrm{O}\left(\mathrm{CH}_{2}\right)_{3} \mathrm{CH}_{3}$ & $>189.3$ & $231.3 \pm 44.5$ & $<1.2$ \\
\hline $22 \mathrm{c}$ & $\mathrm{H}$ & $\mathrm{O}\left(\mathrm{CH}_{2}\right)_{5} \mathrm{CH}_{3}$ & $>102.7$ & $213.3 \pm 47.9$ & $<2.1$ \\
\hline $22 d$ & $\mathrm{H}$ & $\mathrm{O}\left(\mathrm{CH}_{2}\right)_{9} \mathrm{CH}_{3}$ & $>143.6$ & $140.5 \pm 20.7$ & $<1.0$ \\
\hline $24 a$ & $\mathrm{H}$ & $\mathrm{NH}\left(\mathrm{CH}_{2}\right)_{5} \mathrm{CH}_{3}$ & $216.2 \pm 2.5$ & $157.0 \pm 9.7$ & 0.7 \\
\hline $24 b$ & $\mathrm{H}$ & $\mathrm{NH}\left(\mathrm{CH}_{2}\right)_{11} \mathrm{CH}_{3}$ & $3>80.0$ & $147.6 \pm 45.4$ & $<1.8$ \\
\hline $24 c$ & $\mathrm{H}$ & $\begin{array}{c}\mathrm{NH}-\mathrm{o}-\mathrm{C}_{6} \mathrm{H}_{4}- \\
\mathrm{CH}_{3}\end{array}$ & $>101.0$ & $118.7 \pm 10.9$ & $<1.2$ \\
\hline $20 \mathrm{a}(+)$ & $\mathrm{H}$ & $\mathrm{OH}$ & $505.3 \pm 132.6$ & $>48.1$ & $>0.1$ \\
\hline $20 \mathrm{a}(-)$ & $\mathrm{H}$ & $\mathrm{OH}$ & $53.5 \pm 10.8$ & $33.0 \pm 1.5$ & 0.6 \\
\hline $22 \mathrm{~b}(+)$ & $\mathrm{H}$ & $\mathrm{O}\left(\mathrm{CH}_{2}\right)_{3} \mathrm{CH}_{3}$ & $368.0 \pm 24.2$ & $74.9 \pm 52.8$ & 0.2 \\
\hline $22 \mathrm{~b}(-)$ & $\mathrm{H}$ & $\mathrm{O}\left(\mathrm{CH}_{2}\right)_{3} \mathrm{CH}_{3}$ & $53.0 \pm 10.8$ & $28.8 \pm 4.5$ & 0.5 \\
\hline \multicolumn{6}{|c|}{ Acyl hidrazones } \\
\hline \multicolumn{6}{|l|}{ General structure } \\
\hline Compound & $\mathbf{R}_{\mathbf{1}}$ & $\mathbf{R}_{2}$ & $\mathrm{EC}_{50}(\mu \mathrm{M})^{1}$ & $\mathrm{LC}_{50}(\mu \mathrm{M})^{1}$ & $\mathrm{SI}^{2}$ \\
\hline $26 a$ & $\mathrm{C}_{6} \mathrm{H}_{5}$ & $\mathrm{OCH}_{2} \mathrm{CH}_{3}$ & $28.5 \pm 6.3$ & $15.4 \pm 0.2$ & 0.5 \\
\hline $26 b$ & $\mathrm{C}_{5} \mathrm{H}_{4} \mathrm{~N}$ & $\mathrm{OCH}_{2} \mathrm{CH}_{3}$ & $53.2 \pm 41.0$ & $15.2 \pm 0.2$ & 0.3 \\
\hline $26 c$ & $\mathrm{CONH}_{2}$ & $\mathrm{OH}$ & $>188.6$ & $\begin{array}{c}1156.6 \pm \\
339.6\end{array}$ & $<6.1$ \\
\hline
\end{tabular}

${ }^{1}$ Results reported as the mean value \pm standard deviation of the half-maximum concentration in $\mu \mathrm{M} .{ }^{2}$ Selectivity Index $(\mathrm{SI})=\mathrm{LC}_{50} / \mathrm{EC}_{50}$. Bold data represent compounds with high activity against amastigotes of $L$. $(V)$ panamensis.

${ }^{3} \mathrm{ND}=$ not determined because the compounds were inactive at the maximum concentration evaluated. 


\section{Discussion}

Leishmaniasis is a disease that threatens and affects almost $20 \%$ of the world's population, but, there are very few effective drugs available for its treatment, so new molecules are urgently needed. However, this task is a priority for the pharmaceutical industry, so the affected countries must seek their own alternatives. Recently we reported the in vivo leishmanicidal activities of compounds bearing a benzothiopyran scaffold and also the acyl hydrazones derived from chroman and thiochromans $[8,23]$. To optimize their effects, in this work we prepared thirty-two compounds, including thiochromenes, thichroman-4-ones and acyl hydrazones substituted in C-2 or C-3 with carbonyl/nitrile or carboxyl groups.

The compounds can be grouped into three types, according to their activity. The most active were those with $\mathrm{EC}_{50}<20 \mu \mathrm{M}$, those with marginal activity had an $\mathrm{EC}_{50}$ between $20-40 \mu \mathrm{M}$ and the inactive compounds have $\mathrm{EC}_{50}>40$. The most active compounds include three the thiochromenes 8a, 8d, 13d and compound 10d. Substituents at C-2 and C-3 in the former compounds do not have a structural relationship between them. Compound $\mathbf{8 a}$ with a nitrile at $\mathrm{C}-3$ is the most active, but, surprisingly $\mathbf{8 b}$ with a methyl ester is practically inactive, although the methyl ester is considered a nitrile isostere [24].

Compounds $\mathbf{8 d}$ and $\mathbf{1 0 d}$ with an alkyl chain at C-2 showed high leishmanicidal activity, and changing the alkyl chain for a phenyl group resulted in a decrease in anti-leishmanial activity with an increase in the cytotoxicity. Although none of the compounds bearing a phenyl or aryl group at C-2 showed high anti-leishmanial activity most of the 2-arylthiochromenes displayed a marginal activity, indicating promising compounds for further optimization. On the other hand, if the C-3 methyl ketone is substituted by phenyl or aryl groups, the cytotoxicity decreases while maintaining marginal activities between 37.9-43.9 $\mu \mathrm{M}$.

Thiochromenes of type C-3-formyl, 13a,b,c with aryl groups in C-2 have a range of activity similar to compounds $\mathbf{8 e}$ and $\mathbf{1 5 a , b , c}$ all having electron-withdrawing groups. The above seems to indicate that steric factors and pi interactions are involved in the interaction of these compounds with a putative receptor of Leishmania amastigote.

On the other hand, the importance of a C-3 carbonyl substituent is demonstrated in the series of compounds $\mathbf{2 0 a}-\mathbf{d}, \mathbf{2 2} \mathbf{a}-\mathbf{d}$ and $\mathbf{2 4 a}-\mathbf{c}$ all bearing the thiochroman-4-one scaffold without substituents at C-3, which were practically inactive. The previous esters and amides were prepared thinking of performing a SAR study to analyze the effect of chain size on leishmanicidal and cytotoxic activity, but all these compounds showed very low activity.

Surprisingly, two acyl hydrazones 26a and 26b showed a marginal activity EC 5028.5 and $53.2 \mu \mathrm{M}$, unlike the compounds that we have previously analyzed [8], which seems to indicate that the substitution by a C-2 carbonyl of a thiochroman-4-one interferes with its mechanism of action against amastigotes of L. panamensis parasites.

In conclusion, in search of new chemotherapeutic agents against leishmaniasis based on the benzothiopyran moiety, we synthesized thirty-two structurally diverse compounds. These compounds possess relevant in vitro antileishmanial activity with moderate cytotoxicity. Compounds $\mathbf{8 d}$ and $\mathbf{1 0 d}$, which differ only in the hydroxy group at C-4, were the most promising compounds among this library with good antiparasitic activity and Selectivity Index. Biological studies with Leishmania parasite enzymes need to be performed to identify the potential targets. Structural modification on ring A of $\mathbf{8 d}$ and $\mathbf{9 d}, \mathbf{1 0 d}$ could enhance the antileishmanial activity or reduce cytotoxicity. Overall, 8d, 9d, and $10 \mathrm{~d}$ represents potential hits in the search for new chemotherapeutic agents for the treatment of leishmaniasis. 


\section{Materials and Methods}

\subsection{Chemistry}

\subsubsection{General Information}

All commercially available reagents and solvents were obtained from commercial suppliers and used without further purification. The reaction progress was monitored with thin layer chromatography on silica gel TLC aluminum sheets $\left(60 \mathrm{~F}_{254}\right.$, Merck, Darmstadt, Germany). The melting points were determined using a Mel-Temp apparatus (Electrothermal, Staffordshire, UK) and are uncorrected. FTIR spectra were obtained on a Bruker Alpha FTIR spectrometer (Bruker Optic GmbH, Ettlingen, Germany). ${ }^{1} \mathrm{H}$ and ${ }^{13} \mathrm{C}$ nuclear magnetic resonance (NMR) spectra were recorded using Bruker 300 and 400 spectrometers (300 and $400 \mathrm{MHz}$ for $1 \mathrm{H}, 75$, and $100 \mathrm{MHz}$ for ${ }^{13} \mathrm{C}$ ). Chemical shifts were reported relative to internal tetramethyl silane $(\delta 0.00 \mathrm{ppm})$ for ${ }^{1} \mathrm{H}$, and $\mathrm{CDCl}_{3}(\delta 77.0 \mathrm{ppm})$ for ${ }^{13} \mathrm{C}$. HRMS was obtained using Q-TOF quadrupole/orthogonal mass spectrometry (Waters, Milford, MA, USA) in positive mode (reported as $[\mathrm{M}+\mathrm{H}]^{+}$or $[\mathrm{M}+\mathrm{Na}]^{+}$).

\subsubsection{Synthesis of the Benzothiopyranes and Derivatives}

\section{2-(tert-Butylthio)benzaldehyde (3)}

In a screw-capped flask equipped with a stir bar, DMSO (2.0 mL, $0.028 \mathrm{~mol}, 4$ equivalent $)$ and potassium hydroxide (KOH; $470 \mathrm{mg}$, $8.4 \mathrm{mmol}, 1.1$ equivalent) were mixed under nitrogen and stirred at room temperature. After $30 \mathrm{~min}$, the $\mathrm{KOH}$ was crushed with a spatula, and 2-methyl-2-propanethiol $(610 \mu \mathrm{L}, 0.0106 \mathrm{~mol}, 1.5 \mathrm{eq})$ was added, and the mixture was stirred for $20 \mathrm{~min}$. 2-Chlorobenzaldehyde $\left(810 \mu \mathrm{L}, 7.2 \mathrm{mmol}, 1.0\right.$ equivalent) was added, and the reaction was heated to $110^{\circ} \mathrm{C}$ for $90 \mathrm{~min}$. After that, the reaction mixture was diluted with water $(20 \mathrm{~mL})$ and extracted with ethyl acetate $(2 \times 30 \mathrm{~mL})$. The combined organic layers were washed with water $(30 \mathrm{~mL})$ and brine $(30 \mathrm{~mL})$, dried (anhydrous $\mathrm{Na}_{2} \mathrm{SO}_{4}$ ), and concentrated on a rotary evaporator the residue was purified by chromatography using a mixture of $10 \%$ ethyl acetate in hexanes to afford 2-(tert-butylthio)benzaldehyde 15 (980 mg, $70 \%$ yield) along with some unreacted 2-chlorobenzaldehyde. ${ }^{1} \mathrm{H}-\mathrm{NMR}\left(300 \mathrm{MHz}, \mathrm{CDCl}_{3}\right) 10.78(\mathrm{~s}, 1 \mathrm{H})$, $7.98(\mathrm{~d}, J=4.3 \mathrm{~Hz}, 1 \mathrm{H}), 7.62-7.50(\mathrm{~m}, 1 \mathrm{H}), 7.45-7.30(\mathrm{~m}, 1 \mathrm{H}), 1.30(\mathrm{~s}, 9 \mathrm{H})$. GC-MS: $m / z(\%)=194(27)$ $\left[\mathrm{M}^{+}\right], 161(8), 138(100), 77(5)$.

\section{2,2'-Disulfanediyldibenzaldehyde (4)}

A 25-mL round-bottom flask containing 2-(tert-butylthio)benzaldehyde (3, $194 \mathrm{mg}, 1.0 \mathrm{mmol}$, 1 equivalent) was placed in an ice bath. Acetic acid ( $343 \mu \mathrm{L}, 6 \mathrm{mmol}, 6.0$ equivalents), 48\% aqueous $\mathrm{HBr}(343 \mu \mathrm{L}, 3 \mathrm{mmol}, 3.0$ equivalents) and DMSO $(73 \mu \mathrm{L}, 1.0 \mathrm{mmol}, 1.0$ equivalent) were then added to the resulting cooled mixture. The reaction mixture was then allowed to warm to room temperature and then was stirred overnight. The reaction mixture, containing a solid precipitate, was diluted with cold water $(2 \mathrm{~mL})$, filtered, dried and purified by column chromatography using $20 \%$ ethyl acetate in hexanes as eluent to afford 2,2-disulfanediyldibenzaldehyde (4). Yield 73\%. White solid. m.p.: $149-151{ }^{\circ} \mathrm{C} .{ }^{1} \mathrm{H}-\mathrm{NMR}\left(300 \mathrm{MHz}, \mathrm{CDCl}_{3}\right) \delta 10.19$ (s, 2H), 7.85 (dd, J = 7.5, 1.4 Hz, 2H), 7.75 (d, $J=7.8 \mathrm{~Hz}, 2 \mathrm{H}), 7.47(\mathrm{td}, J=7.7,1.6 \mathrm{~Hz}, 2 \mathrm{H}), 7.37(\mathrm{dd}, J=10.6,4.2 \mathrm{~Hz}, 2 \mathrm{H}) .{ }^{13} \mathrm{C}-\mathrm{NMR}\left(75 \mathrm{MHz}, \mathrm{CDCl}_{3}\right)$ $\delta 192.1,140.2,135.0,134.5,134.0,126.8,126.5$. IR v: 1664, 1582, 1555. GC-MS: $m / z(\%)=274(14)\left[\mathrm{M}^{+}\right]$, 137 (100), 109 (54). HRMS-ESI (m/z): calcd. for $\mathrm{C}_{14} \mathrm{H}_{10} \mathrm{O}_{2} \mathrm{~S}_{2}[\mathrm{M}+\mathrm{Na}]^{+}$297.0014, found: 297.0025.

\section{2-Mercaptobenzaldehyde (5)}

In a $25 \mathrm{~mL}$ round bottom flask, 2,2-disulfanediyldibenzaldehyde (4, $177 \mathrm{mg}, 0.65 \mathrm{mmol}, 1$ equivalent), was dissolved in a mixture of DMF $(5.4 \mathrm{~mL}), \mathrm{MeOH}(5.4 \mathrm{~mL})$ and of water $(3.0 \mathrm{~mL}$; all solvents were deoxygenated before use) then tripheylphosphine ( $253 \mathrm{mg}, 0.975 \mathrm{mmol}, 1.5$ equivalent) was added, and the mixture stirred a room temperature for $30 \mathrm{~min}$. After that the reaction mixture was 
diluted with water $(20 \mathrm{~mL})$ and extracted with deoxygenated diethyl ether $(2 \times 30 \mathrm{~mL})$. The combined organic layers were washed with deoxygenated water $(30 \mathrm{~mL})$ and brine $(30 \mathrm{~mL})$, dried (anhydrous $\mathrm{Na}_{2} \mathrm{SO}_{4}$ ), and concentrated on a rotary evaporator the residue was purified by chromatography using a mixture of $10 \%$ ethyl acetate in hexanes to afford 2-mercaptobenzaldehyde (5), in 73\% yield. During the whole process, the presence of air in the mixture was avoided to prevent oxidation back to the disulfide 4. ${ }^{1} \mathrm{H}-\mathrm{NMR}\left(300 \mathrm{MHz}, \mathrm{CDCl}_{3}\right) \delta 10.02(\mathrm{~s}, 1 \mathrm{H}), 7.73(\mathrm{dd}, J=8.5,7.7 \mathrm{~Hz}, 1 \mathrm{H}), 7.38-7.20(\mathrm{~m}$, $3 \mathrm{H}), 5.48$ (s, 1H).

\section{H-Thiochromene-3-carbonitrile (8a)}

In a round-bottom flask were placed 2,2-disulfanediyl-dibenzaldehyde $(4,137 \mathrm{mg}, 0.5 \mathrm{mmol}$, 1 equivalent), acrylonitrile $58 \mathrm{mg}(0.55 \mathrm{mmol}, 2.2$ equivalents) and DBU $84 \mathrm{mg}$ (0.55 mmol, 1.1 equivalents) under nitrogen, and the mixture was heated with stirring at $80{ }^{\circ} \mathrm{C}$ for $24 \mathrm{~h}$, After cooling to room temperature, the crude reaction mixture was then purified by column chromatography over silica gel using hexane/EtOAc (5:1) as eluent to afford 7a as a white solid (77 mg, 45\%). Alternatively, $2 \mathrm{H}$-thiochromene-3-carbonitrile (7a) was prepared by a different methodology, as follows:

Step 1. In a screw-capped flask, 2,2-disulfanediyl-dibenzaldehyde $(4,70 \mathrm{mg}, 0.25 \mathrm{mmol}, 1$ equivalent); triphenylphosphine $131 \mathrm{mg}$ ( $0.5 \mathrm{mmol}, 2$ equivalents) were dissolved in THF (5 mL), the mixture was stirred at room temperature under an argon atmosphere. After 20 min an excess of acrylonitrile ( $80 \mathrm{mg}, 1.5 \mathrm{mmol}, 6$ equivalents) was added and after another $10 \mathrm{~min}$ of reaction a TLC plate showed the formation of 2-mercaptobenzaldehyde (5) and the mixture of stereoisomers of 4-hydroxy-thiochromane-3-carbonitrile. The reaction mixture is stirred overnight, and after that time, the only products are the 4-hydroxythiochromane-3-carbonitriles.

Step 2. The mixture of 4-hydroxythiochromane-3-carbonitriles is heated overnight at reflux in dichloroethane with $20 \%$ mol of Amberlyst 15 after that, the solvent was evaporated on a rotary evaporator and diluted in the minimum amount of $\mathrm{CH}_{2} \mathrm{Cl}_{2}$ and purified by column chromatography using a mixture of $20 \%$ ethyl acetate in hexanes as eluent to afford $2 H$-thiochromene-3-carbonitrile $8 \mathbf{a}$ in $68 \%$ yield (calculated from the dimer). Mp. 96-98 ${ }^{\circ} \mathrm{C} .{ }^{1} \mathrm{H}-\mathrm{NMR}\left(400 \mathrm{MHz}, \mathrm{CDCl}_{3}\right) \delta 7.30-7.19$ $(\mathrm{m}, J=7.5 \mathrm{~Hz}, 2 \mathrm{H}), 7.20-7.10(\mathrm{~m}, 3 \mathrm{H}), 3.57(\mathrm{~s}, 2 \mathrm{H}) .{ }^{13} \mathrm{C}-\mathrm{NMR}\left(101 \mathrm{MHz}, \mathrm{CDCl}_{3}\right) \delta 142.4,132.9,131.1$, $130.3,130.3,127.7,126.5,118.5,103.9,26.0$. IR v: 2207, 1615, 1435, 753. HRMS-ESI $(\mathrm{m} / \mathrm{z})$ : calcd. for $\mathrm{C}_{10} \mathrm{H}_{7} \mathrm{NS}[\mathrm{M}+\mathrm{H}]^{+} 174.0372$, found: 174.0380 .

\section{Methyl 2H-thiochromene-3-carboxylate (8b)}

In a screw-capped flask, 2,2-disulfanediyldibenzaldehyde (4, $137 \mathrm{mg}, 0.5 \mathrm{mmol}, 1$ equivalent), methylacrylate (130 mg, $1.5 \mathrm{mmol}, 3.0$ equivalents) and DBU (230 mg, $1.5 \mathrm{mmol}, 3.0$ equivalents) were mixed under an argon atmosphere and then heated to $80^{\circ} \mathrm{C}$ for $24 \mathrm{~h}$, After cooling to room temperature the reaction mixture was dissolved with $\mathrm{CH}_{2} \mathrm{Cl}_{2}$ and poured directly onto a chromatography column that was eluted using $10 \%$ ethyl acetate in hexanes to afford methyl $2 \mathrm{H}$-thiochromene-3-carboxylate (8b) in $48 \%$ yield as a yellowish solid with mp. $34-35{ }^{\circ} \mathrm{C} .{ }^{1} \mathrm{H}-\mathrm{NMR}\left(400 \mathrm{MHz}, \mathrm{CDCl}_{3}\right) \delta 7.55\left(\mathrm{~s},{ }^{1} \mathrm{H}\right)$, $7.30-7.16(\mathrm{~m}, 3 \mathrm{H}), 7.13(\mathrm{~d}, J=7.4 \mathrm{~Hz}, 3 \mathrm{H}), 3.84(\mathrm{~s}, 3 \mathrm{H}), 3.73(\mathrm{~s}, 2 \mathrm{H}) .{ }^{13} \mathrm{C}-\mathrm{NMR}\left(100 \mathrm{MHz}, \mathrm{CDCl}_{3}\right) \delta$ 166.4, 137.3, 134.0, 131.3, 130.6, 130.2, 127.1, 125.8, 123.0, 52.2, 24.0. IR v: 2952, 1703, 1434, $1235,751$. HRMS-ESI $(m / z)$ : calcd. for $\mathrm{C}_{11} \mathrm{H}_{10} \mathrm{O}_{2} \mathrm{~S}[\mathrm{M}+\mathrm{H}]^{+}$207.0474, found: 207.0185.

\section{1-(2-Phenyl-2H-thiochromen-3-yl)ethan-1-one (8c)}

In a $10 \mathrm{~mL}$ round bottom flask equipped with a reflux condenser were added (E)-4-phenylbut-3-en-2-one (146 mg, $1.0 \mathrm{mmol})$ and 2-(tert-butylthio)benzaldehyde (3, $250 \mathrm{mg}, 1.3 \mathrm{mmol})$ and to this mixture was added concentrated hydrochloric acid (12M, $2.0 \mathrm{~mL})$ and the mixture was placed in a preheated oil bath at $110{ }^{\circ} \mathrm{C}$ and held for two hours. Thereafter water $(10 \mathrm{~mL}) \mathrm{was}$ added and the mixture was extracted with dichloromethane $(3 \times 15 \mathrm{~mL})$, the combined organic layers were washed with saturated $\mathrm{NaHCO}_{3}$ solution. After drying over $\mathrm{Na}_{2} \mathrm{SO}_{4}$, the solvent was evaporated, and the residue was purified by column chromatography to yield $106 \mathrm{mg}(40 \%)$ of 
1-(2-phenyl-2H-thio-chromen-3-yl)ethan-1-one 27, as a yellowish solid. Mp: $115-116{ }^{\circ} \mathrm{C} .{ }^{1} \mathrm{H}-\mathrm{NMR}$ $\left(400 \mathrm{MHz}, \mathrm{CDCl}_{3}\right) \delta 7.67(\mathrm{~s}, 1 \mathrm{H}), 7.38(\mathrm{~d}, J=7.8 \mathrm{~Hz}, 1 \mathrm{H}), 7.25(\mathrm{dd}, J=3.9,2.8 \mathrm{~Hz}, 1 \mathrm{H}), 7.21-7.13$ $(\mathrm{m}, 5 \mathrm{H}), 5.36(\mathrm{~d}, J=1.6 \mathrm{~Hz}, 1 \mathrm{H}), 2.49(\mathrm{~s}, 3 \mathrm{H}) .{ }^{13} \mathrm{C}-\mathrm{NMR}\left(101 \mathrm{MHz}, \mathrm{CDCl}_{3}\right) \delta$ 196.5, 142.0, 137.4, 134.0, 132.8, 131.1, 130.7, 130.4, 128.5, 127.6, 127.6, 126.5, 125.7, 38.8, 25.6. IR v: 3031, 1656, 1622, 1196, 900. HRMS-ESI $(m / z)$ : calcd. for $\mathrm{C}_{17} \mathrm{H}_{14} \mathrm{OS}[\mathrm{M}+\mathrm{H}]^{+} 267.0838$, found: 267.0345 .

\section{1-(2-Pentyl-2H-thiochromen-3-yl)ethan-1-one (8d)}

In a $10 \mathrm{~mL}$ round bottom flask were added 2,2-disulfanediyldibenzaldehyde (4, $140 \mathrm{mg}, 0.5$ $\mathrm{mmol})$, 2-Nonanone (145 mg, $1.0 \mathrm{mmol}$ ) and triphenylphosphine (262 mg, $1.0 \mathrm{mmol})$ dissolved in THF $(5 \mathrm{~mL})$ and the mixture was stirred under an argon atmosphere at room temperature overnight. Column chromatography of the crude residue after solvent removal gave $195 \mathrm{mg}(70 \%)$ of a mixture of stereoisomers of 1-(4-hydroxy-2-pentylthiochroman-3-yl)ethan-1-one. Later $140 \mathrm{mg}$ of the isomeric alcohols was dissolved in THF ( $5 \mathrm{~mL}$ containing Amberlyst $15(20 \% \mathrm{~mol})$ in a $10 \mathrm{~mL}$ round bottom flask equipped with a reflux condenser and the mixture was heated to reflux overnight during $20 \mathrm{~h}$. After cooling to room temperature the reaction mixture was dissolved with $\mathrm{CH}_{2} \mathrm{Cl}_{2}$ and the crude was purified by column chromatography over silica gel using hexane/EtOAc (9:1) as eluent to afford $40 \mathrm{mg}$ (29\%) of 1-(2-pentyl-2H-thiochromen-3-yl)ethan-1-one (8d) as a yellowish oil. ${ }^{1} \mathrm{H}-\mathrm{NMR}(400 \mathrm{MHz}$, $\left.\mathrm{CDCl}_{3}\right) \delta 7.45(\mathrm{~s}, 1 \mathrm{H}), 7.37(\mathrm{~d}, J=8.0 \mathrm{~Hz}, 1 \mathrm{H}), 7.34-7.24(\mathrm{~m}, 2 \mathrm{H}), 7.20(\mathrm{td}, J=7.3,1.4 \mathrm{~Hz}, 1 \mathrm{H}), 4.11(\mathrm{dd}$, $J=8.0,5.6 \mathrm{~Hz}, 1 \mathrm{H}), 2.52(\mathrm{~s}, 3 \mathrm{H}), 1.47(\mathrm{dt}, J=10.8,3.7 \mathrm{~Hz}, 2 \mathrm{H}), 1.35-1.15(\mathrm{~m}, 6 \mathrm{H}), 0.88(\mathrm{t}, J=6.8 \mathrm{~Hz}, 3 \mathrm{H}$. ${ }^{13} \mathrm{C}-\mathrm{NMR}\left(75 \mathrm{MHz}, \mathrm{CDCl}_{3}\right) \delta 196.8,136.4,133.3,130.8,130.6,128.1,125.5,36.2,34.4,31.2,25.7,25.5$, $22.5,14.1$. Note: the signals at 130.6 and 133.3 each correspond to two overlapped peaks. IR v: 2927 , $1635,1407,1388,756$. HRMS-ESI $(m / z)$ : calcd. for $\mathrm{C}_{16} \mathrm{H}_{20} \mathrm{OS}[\mathrm{M}+\mathrm{H}]^{+} 261.1308$, found: 261.1320.

\section{4-Oxo-thiochromane-3-carbonitrile (9a)}

According with Step 1 of the procedure for the synthesis of compound 8a we prepared a mixture of stereoisomers of 4-hydroxythiochromane-3-carbonitrile, then this mixture (191 mg, $1.0 \mathrm{mmol}$ ) was dissolved in dichloromethane $(5.0 \mathrm{~mL})$ and mixed with the Dess-Martin periodinane reagent ( $430 \mathrm{mg}, 1 \mathrm{mmol}$ ). After $1 \mathrm{~h}$ of stirring at room temperature the crude mixture was purified by column chromatography over silica gel using hexane/EtOAc (4:1) as eluent to afford the desired 4-oxothiochromane-3-carbonitrile $(9 \mathrm{a}, 60 \mathrm{mg}, 30 \%)$ as a white solid with $\mathrm{mp}$ : $79-81^{\circ} \mathrm{C} .{ }^{1} \mathrm{H}-\mathrm{NMR}$ $\left(300 \mathrm{MHz}, \mathrm{CDCl}_{3}\right) \delta{ }^{1} \mathrm{H} \mathrm{NMR}\left(300 \mathrm{MHz}, \mathrm{CDCl}_{3}\right) \delta 8.17(\mathrm{dd}, J=8.0,1.4 \mathrm{~Hz}, 1 \mathrm{H}), 7.61-7.44(\mathrm{~m}, 1 \mathrm{H})$, 7.42-7.21 (m, 2H), $4.18(\mathrm{dd}, J=11.6,3.7 \mathrm{~Hz}, 1 \mathrm{H}), 3.67(\mathrm{dd}, J=13.5,11.7 \mathrm{~Hz}, 1 \mathrm{H}), 3.57-3.40(\mathrm{~m}, 1 \mathrm{H})$. ${ }^{13} \mathrm{C}-\mathrm{NMR}\left(75 \mathrm{MHz}, \mathrm{CDCl}_{3}\right) \delta 184.6,141.0,134.7,130.5,128.9,127.7,126.0,115.1,41.8,29.4$. IR v: 2918, 2256, 1678, 1582, 1430. HRMS-ESI $(m / z)$ : calcd. for $\mathrm{C}_{10} \mathrm{H}_{7} \mathrm{NOS}[\mathrm{M}+\mathrm{Na}]^{+} 212.0141$, found: 212.0153 .

\section{Methyl 4-oxo-thiochromane-3-carboxylate $(\mathbf{9 b}, \mathbf{1 0 b})$}

In a screw-capped flask, 2,2-disulfanediyl-dibenzaldehyde (4, $70 \mathrm{mg}, 0.25 \mathrm{mmol}, 1$ equivalent) and triphenylphosphine (131 $\mathrm{mg}$ ( $0.5 \mathrm{mmol}, 2$ equivalents), were dissolved in THF ( $5 \mathrm{~mL})$, and the mixture was stirred at room temperature under an argon atmosphere. After $20 \mathrm{~min}$ an excess of acrylonitrile ( $80 \mathrm{mg}, 1.5 \mathrm{mmol}, 6$ equivalents) was added and after another $10 \mathrm{~min}$ of reaction a TLC plate showed the formation of 2-mercaptobenzaldehyde (5) and a mixture of 3-cyano-4-hydroxy-2H-thiochroman isomers. The reaction mixture was stirred overnight, and after that, the only products are the mixture of stereoisomers of 3-cyano-4-hydroxy-2H-thiochroman. A portion of the above mixture $(112 \mathrm{mg})$ was dissolved in dichloromethane $(5.0 \mathrm{~mL})$ and mixed with the Dess-Martin periodinane reagent ( $430 \mathrm{mg}, 1 \mathrm{mmol}$ ). After $1 \mathrm{~h}$ of stirring at room temperature, the crude mixture was purified by column chromatography to afford $40 \mathrm{mg}(36 \%)$ of the desired methyl 4-oxo-thiochromane-3-carboxylate as a white solid with mp: $85-86^{\circ} \mathrm{C}$. Methyl 4-oxo-thiochromane-3-carboxylate $(9 \mathrm{~b})$ exists in solution in equilibria with its tautomeric methyl 4-hydroxy- $2 \mathrm{H}$-thiochromene-3-carboxylate enol form $10 \mathrm{~b}$. The ${ }^{1} \mathrm{H}-\mathrm{NMR}$ spectrum in $\mathrm{CDCl}_{3}$ revealed the that the ratio of tautomers $9 \mathbf{b}$ and $10 \mathbf{b}$ was $1: 5$. Proton $\mathrm{H} 5$ appears as a doublet at $8.17 \mathrm{ppm}, J=7.9 \mathrm{~Hz}$, the proton $\mathrm{H} 5$ of the enol form has a chemical shift of 
$7.89 \mathrm{~d}, \mathrm{~J}=7.7 \mathrm{~Hz}$ the integration areas are 0.2 and 1.0 respectively, which indicates that the enol form corresponds to $83 \%$ of the mixture. The same ratio can be calculated with the protons of the methoxy group of the ester. ${ }^{1} \mathrm{H}-\mathrm{NMR}\left(300 \mathrm{MHz}, \mathrm{CDCl}_{3}\right) \delta 12.71^{\mathrm{a}}(\mathrm{s}), 8.17^{\mathrm{b}}(\mathrm{d}, J=7.9 \mathrm{~Hz}), 7.89^{\mathrm{a}}(\mathrm{d}, J=7.7 \mathrm{~Hz})$, $7.44^{\mathrm{b}}(\mathrm{t}, J=7.6 \mathrm{~Hz}), 7.37-7.19^{\mathrm{a}, \mathrm{b}}(\mathrm{m}), 3.89^{\mathrm{a}}(\mathrm{s}), 3.85^{\mathrm{b}}(\mathrm{s}), 3.76^{\mathrm{a}}(\mathrm{s}),, 3.38^{\mathrm{b}}(\mathrm{dd}, J=13.5,3.6 \mathrm{~Hz})\left({ }^{\mathrm{a}}\right.$ is the enol form, ${ }^{b}$ is the keto form); ${ }^{13} \mathrm{C}-\mathrm{NMR}\left(75 \mathrm{MHz}, \mathrm{CDCl}_{3}\right) \delta 171.6,165.9,137.2,131.0,129.8,129.2,127.3$, 126.8, 125.6, 125.3, 93.7, 77.5, 77.1, 76.7, 54.0, 52.7, 52.1, 23.3; IR v: 3012, 2951, 1718, 1681, 1645, 1608, 1583, 1553, 1437. HRMS-ESI $\left(\mathrm{m} / \mathrm{z}\right.$ ): calcd. for $\mathrm{C}_{11} \mathrm{H}_{10} \mathrm{O}_{3} \mathrm{~S}[\mathrm{M}+\mathrm{Na}]^{+} 245.0243$, found: 245.0254 .

\section{1-(4-Hydroxy-2-pentyl-2H-thiochromen-3-yl)ethan-1-one (10d)}

In a $10 \mathrm{~mL}$ round bottom flask were added 2,2-disulfanediyldibenzaldehyde $17,(140 \mathrm{mg}, 0.5 \mathrm{mmol})$, 2-nonanone, (145 mg, $1.0 \mathrm{mmol})$ and triphenylphosphine $(262 \mathrm{mg}, 1.0 \mathrm{mmol})$, and the mixture was stirred under an argon atmosphere at room temperature overnight. Column chromatography of the crude residue after solvent removal gave $195 \mathrm{mg}(70 \%)$ of a mixture of stereoisomers of 1-(4-hydroxy-2-pentylthiochroman-3-yl)ethan-1-one (10d). Next, $90 \mathrm{mg}$ of this mixture were dissolved in dichloromethane $(5.0 \mathrm{~mL})$ and mixed with the Dess-Martin periodinane reagent $(192 \mathrm{mg}, 0.45 \mathrm{mmol})$ and water $(1.0 \mathrm{~mL})$. After stirring for $1 \mathrm{~h}$ at room temperature the crude mixture was purified by column chromatography to afford $55 \mathrm{mg}(60 \%)$ of the desired product as a yellowish oil which exists in solution only as its enol form 1-(4-hydroxy-2-pentyl-2H-thiochromen-3-yl)ethan-1-one. ${ }^{1} \mathrm{H}-\mathrm{NMR}$ $\left(400 \mathrm{MHz}, \mathrm{CDCl}_{3}\right) \delta 7.97(\mathrm{ddd}, J=7.9,1.4,0.5 \mathrm{~Hz}, 1 \mathrm{H}), 7.36-7.25(\mathrm{~m}, 2 \mathrm{H}), 7.22(\mathrm{ddd}, J=7.9,7.0$, $1.6 \mathrm{~Hz}, 1 \mathrm{H}), 3.67(\mathrm{dd}, J=9.6,5.0 \mathrm{~Hz}, 1 \mathrm{H}), 2.31(\mathrm{~s}, J=1.8 \mathrm{~Hz}, 3 \mathrm{H}), 1.77-1.65(\mathrm{~m}, 1 \mathrm{H}), 1.63-1.43(\mathrm{~m}, 2 \mathrm{H})$, $1.36-1.09(\mathrm{~m}, 5 \mathrm{H}), 0.85(\mathrm{t}, J=7.0 \mathrm{~Hz}, 3 \mathrm{H}) .{ }^{13} \mathrm{C}-\mathrm{NMR}(101 \mathrm{MHz}, \mathrm{MeOH}) \delta 195.4,174.0,135.8,132.0,129.5$, 128.2, 127.7, 125.5, 108.8, 39.6, 36.4, 31.1, 26.6, 24.4, 22.5, 14.0. IR v: 2928, 2856, 1634, 1593, 1545, 1380. HRMS-ESI $(\mathrm{m} / \mathrm{z})$ : calcd. for $\mathrm{C}_{16} \mathrm{H}_{20} \mathrm{O}_{2} \mathrm{~S}[\mathrm{M}+\mathrm{Na}]^{+} 299.1076$, found: 299.1088 .

\section{H,12H-6,12-Epoxydibenzo[b,f][1,5]dithiocine (11)}

In a $10 \mathrm{~mL}$ round bottom flask equipped with a reflux condenser containing concentrated hydrochloric acid (12M, 3.0 mL) was added 2-(tert-butylthio)benzaldehyde (3, 582 mg, $3.0 \mathrm{mmol})$. This mixture was placed in a preheated oil bath at $110^{\circ} \mathrm{C}$ and held for $2 \mathrm{~h}$, after which water $(10 \mathrm{~mL})$ was added and the mixture was extracted with dichloromethane $(3 \times 15 \mathrm{~mL})$ and the combined organic layers were washed with saturated $\mathrm{NaHCO}_{3}$ solution. After drying over $\mathrm{Na}_{2} \mathrm{SO}_{4}$, the solvent was evaporated, and the residue was purified by column chromatography over silica gel using hexane/EtOAc (4:1) as eluent to yield $282 \mathrm{mg}$, (72\%) of 6H,12H-6,12-epoxydibenzo[b,f][1,5]dithiocine with m.p.: $160-161^{\circ} \mathrm{C} .{ }^{1} \mathrm{H}-\mathrm{NMR}\left(300 \mathrm{MHz}, \mathrm{CDCl}_{3}\right) \delta 7.36-7.31(\mathrm{~m}, 1 \mathrm{H}), 7.17-7.05(\mathrm{~m}, 3 \mathrm{H}), 6.40(\mathrm{~s}, 1 \mathrm{H})$. ${ }^{13} \mathrm{C}-\mathrm{NMR}\left(75 \mathrm{MHz}, \mathrm{CDCl}_{3}\right) \delta 132.7,129.0,128.3,127.9,125.2,74.7$. IR v: 3051, 1433, 1262, 1083, 956, 726. GC-MS: $m / z(\%)=258(40)\left[\mathrm{M}^{+}\right], 153(100), 121(15), 77(28)$.

\subsubsection{General Procedure for the Synthesis of 2-aryl-2H-thiochromene-3-carbaldehydes 13a-d}

In a $10 \mathrm{~mL}$ round bottom flask equipped with a reflux condenser were added the corresponding cinnamaldehyde $(1.0 \mathrm{mmol})$ and 2-(tert-butylthio)benzaldehyde $(3,1.3 \mathrm{mmol})$ and to this mixture was added concentrated hydrochloric acid $(12 \mathrm{M}, 2.0 \mathrm{~mL})$. Then, the mixture was placed in a preheated oil bath at $110^{\circ} \mathrm{C}$ and held for two hours, after which water $(10 \mathrm{~mL})$ was added and the mixture was extracted with dichloromethane $(3 \times 15 \mathrm{~mL})$, and the combined organic layers were washed with saturated $\mathrm{NaHCO}_{3}$ solution. After drying over $\mathrm{Na}_{2} \mathrm{SO}_{4}$, the solvent was evaporated, and the residue was purified by column chromatography over silica gel using hexane/EtOAc (4:1) as eluent to yield the corresponding 2-aryl-2H-thiochromene-3-carbaldehyde 13a-d.

\section{2-Phenyl-2H-thiochromene-3-carbaldehyde (13a)}

Starting from cinnamaldehyde, according to the general procedure described above, 2-phenyl-2H-thiochromene-3-carbaldehyde (13a, $175 \mathrm{mg}, 70 \%)$ was obtained as a yellowish solid with mp: $195-196{ }^{\circ} \mathrm{C} .{ }^{1} \mathrm{H}-\mathrm{NMR}\left(200 \mathrm{MHz}, \mathrm{CDCl}_{3}\right) \delta 9.70$ (s, 1H), 7.55 (s, 1H), 7.43 (m, 1H), 7.35-7.19 (m, 5H), 
$7.10(\mathrm{~s}, 1 \mathrm{H}), 4.80(\mathrm{~s}, 1 \mathrm{H})$. IR $v: 3040,2820,1660,1622,1139$. HRMS-ESI $(\mathrm{m} / \mathrm{z})$ : calcd. for $\mathrm{C}_{16} \mathrm{H}_{12} \mathrm{OS}[\mathrm{M}+$ $\mathrm{Na}^{+}$275.0501, found: 275.0510 .

\section{2-(4-Fluorophenyl)-2H-thiochromene-3-carbaldehyde (13b)}

Starting from 4-fluorocinnamaldehyde $(150 \mathrm{mg}, 1.0 \mathrm{mmol})$ according to the general procedure described above 2-(4-fluorophenyl)-2H-thiochromene-3-carbaldehyde (13b, $160 \mathrm{mg}$, 59\% yield) was obtained as a yellow solid with m.p.: $96-98{ }^{\circ} \mathrm{C} .{ }^{1} \mathrm{H}-\mathrm{NMR}\left(400 \mathrm{MHz}, \mathrm{CDCl}_{3}\right) \delta 9.66(\mathrm{~s}, 1 \mathrm{H}), 7.47(\mathrm{~s}, 1 \mathrm{H})$, $7.42(\mathrm{~d}, J=7.6 \mathrm{~Hz}, 1 \mathrm{H}), 7.35-7.25(\mathrm{~m}, 2 \mathrm{H}), 7.24-7.12(\mathrm{~m}, 3 \mathrm{H}), 6.86(\mathrm{dd}, J=12.6,4.8 \mathrm{~Hz}, 2 \mathrm{H}), 5.19(\mathrm{~s}, 1 \mathrm{H})$. ${ }^{13} \mathrm{C}-\mathrm{NMR}\left(101 \mathrm{MHz}, \mathrm{CDCl}_{3}\right) \delta 191.3,162.5(\mathrm{~d}, J=246.5 \mathrm{~Hz}), 145.4,137.7,134.9,134.0,132.1,131.3,129.9$, $128.4(\mathrm{~d}, J=8.2 \mathrm{~Hz}), 127.9,126.2,115.7(\mathrm{~d}, J=21.6 \mathrm{~Hz}), 37.8$. IR v: 3050, 2826, 1665, 1625, 1503, 1139, 845. HRMS-ESI $(m / z)$ : calcd. for $\mathrm{C}_{16} \mathrm{H}_{11} \mathrm{FOS}[\mathrm{M}+\mathrm{Na}]^{+}$293.0407, found: 293.0416 .

\section{2-(4-Chlorophenyl)-2H-thiochromene-3-carbaldehyde (13c)}

Starting from 4-chlorocinnamaldehyde $(174 \mathrm{mg}, 1.0 \mathrm{mmol})$ according to the general procedure described above 2-(4-chlorophenyl)-2H-thiochromene-3-carbaldehyde (13c, $250 \mathrm{mg}, 87 \%$ yield) was obtained as a yellow solid with m.p.: $119-120{ }^{\circ} \mathrm{C} .{ }^{1} \mathrm{H}-\mathrm{NMR}\left(400 \mathrm{MHz}, \mathrm{CDCl}_{3}\right) \delta 9.67(\mathrm{~s}, 1 \mathrm{H}), 7.48$ (s, $1 \mathrm{H}), 7.42(\mathrm{~d}, J=7.4 \mathrm{~Hz}, 1 \mathrm{H}), 7.34-7.25(\mathrm{~m}, 2 \mathrm{H}), 7.21(\mathrm{td}, J=7.3,1.1 \mathrm{~Hz}, 1 \mathrm{H}), 7.17-7.11(\mathrm{~m}, 4 \mathrm{H}), 5.17$ (s, 1H). ${ }^{13} \mathrm{C}-\mathrm{NMR}\left(101 \mathrm{MHz}, \mathrm{CDCl}_{3}\right) \delta 191.1,145.3,140.3,140.1,134.5,133.6,132.0,131.1,129.7,128.8$, 127.9, 127.7, 126.1, 37.7. IR v: 2845, 1667, 1627, 1580. 1138, 761. HRMS-ESI $(\mathrm{m} / \mathrm{z})$ : calcd. for $\mathrm{C}_{16} \mathrm{H}_{11} \mathrm{ClOS}$ $[\mathrm{M}+\mathrm{Na}]^{+}$309.0111, found: 309.0120 .

\section{2-(2-Nitrophenyl)-2H-thiochromene-3-carbaldehyde (13d)}

Starting from 2-nitrocinnamaldehyde $(1.0 \mathrm{mmol})$ according to the general procedure described above 2-(4-chlorophenyl)-2H-thiochromene-3-carbaldehyde (13d, $410 \mathrm{mg}, 69 \%$ yield) was obtained as a yellow solid with m.p.: $130-132{ }^{\circ} \mathrm{C} .{ }^{1} \mathrm{H}-\mathrm{NMR}(400 \mathrm{MHz}, \mathrm{CDCl} 3) \delta 9.66(\mathrm{~d}, J=1.7 \mathrm{~Hz}, 1 \mathrm{H}), 8.01$ $(\mathrm{d}, J=7.1 \mathrm{~Hz}, 1 \mathrm{H}), 7.67(\mathrm{~s}, 1 \mathrm{H}), 7.45(\mathrm{~d}, J=7.4 \mathrm{~Hz}, 1 \mathrm{H}), 7.35(\mathrm{p}, J=7.5 \mathrm{~Hz}, 2 \mathrm{H}), 7.29(\mathrm{~d}, J=7.5 \mathrm{~Hz}$, 1H), 7.26-7.15 (m, 2H), $7.10(\mathrm{~d}, J=7.1 \mathrm{~Hz}, 1 \mathrm{H}), 6.01(\mathrm{~s}, 1 \mathrm{H}) .{ }^{13} \mathrm{C}-\mathrm{NMR}\left(101 \mathrm{MHz}, \mathrm{CDCl}_{3}\right) \delta$ 190.7, 147.1, $146.4,135.8,133.9,133.5,133.2,132.3,131.2,129.2,128.5,128.4,127.8,126.2,125.9,33.4$. IR v: 2992, 1661, 1623, 1519, 1142, 740. GC-MS: $m / z(\%)=297(4)\left[\mathrm{M}^{+}\right], 280$ (43), 251 (60), 235 (44), 221 (100.). HRMS-ESI $(\mathrm{m} / \mathrm{z})$ : calcd. for $\mathrm{C}_{16} \mathrm{H}_{11} \mathrm{NO}_{3} \mathrm{~S}[\mathrm{M}+\mathrm{Na}]^{+} 320.0352$, found: 320.0362 .

\section{Phenyl(2-phenyl-2H-thiochromen-3-yl)methanone (15a)}

In a $10 \mathrm{~mL}$ round bottom flask equipped with a reflux condenser were added chalcone $(1 \mathrm{mmol})$, 2-(tert-butylthio)benzaldehyde (3, $1.5 \mathrm{mmol})$ and $p$-toluenesulfonic acid monohydrate $(60 \mathrm{mg})$ in toluene $(2 \mathrm{~mL})$. The reaction mixture was stirred at reflux for $2 \mathrm{~h}$ and progress of the reaction was monitored with TLC. Upon the consumption of the chalcone, the reaction mixture was directly subjected to column chromatography over silica gel using hexane/EtOAc (5:1) as eluent to give the desired compound as a yellow solid $(45 \mathrm{mg}, 46 \%)$ m.p.:. $151-153{ }^{\circ} \mathrm{C} .{ }^{1} \mathrm{H}-\mathrm{NMR}\left(400 \mathrm{MHz}, \mathrm{CDCl}_{3}\right) \delta 7.71$ (dd, $J=8.3,1.3 \mathrm{~Hz}, 2 \mathrm{H}), 7.57(\mathrm{ddd}, J=6.7,2.7,1.3 \mathrm{~Hz}, 1 \mathrm{H}), 7.51-7.44(\mathrm{~m}, 2 \mathrm{H}), 7.41(\mathrm{~s}, 1 \mathrm{H}), 7.33-7.18(\mathrm{~m}, 8 \mathrm{H})$, $7.14(\mathrm{tdd}, J=7.7,5.9,1.6 \mathrm{~Hz}, 1 \mathrm{H}), 5.49$ (s, $1 \mathrm{H}) .{ }^{13} \mathrm{C}-\mathrm{NMR}\left(101 \mathrm{MHz}, \mathrm{CDCl}_{3}\right) \delta 195.9,142.1,140.2,138.3$, 133.4, 132.9, 132.1, 131.3, 131.0, 130.6, 129.4, 128.9, 128.6, 127.9, 127.8, 126.8, 125.9, 40.4. IR v: 3126, 2918, 1640, 1596, 1488, 1087, 756. HRMS-ESI $(\mathrm{m} / \mathrm{z})$ : calcd. for $\mathrm{C}_{22} \mathrm{H}_{16} \mathrm{OS}[\mathrm{M}+\mathrm{H}]^{+} 329.0995$, found: 329.1002 .

\subsubsection{General Procedure for the Synthesis of}

(4-chlorophenyl)(2-(aryl)-2H-thiochromen-3-yl)methanones 15b,c

In a $10 \mathrm{~mL}$ round bottom flask equipped with a reflux condenser were mixed 4'-chloro-acetophenone $(155 \mathrm{mg}, 1.0 \mathrm{mmol})$ and the appropriate substituted benzaldehyde $(1.0 \mathrm{mmol})$ with Amberlyst- $15(250 \mathrm{mg})$ in toluene $(5 \mathrm{~mL})$. The reaction mixture was stirred at room temperature for $2 \mathrm{~h}$, and the progress of the reaction was monitored with TLC until the formation of the corresponding chalcone was complete. Afterward 2-(tert-butylthio)benzaldehyde 3 (194 mg, $1.0 \mathrm{mmol}$ ) was added, 
and the mixture was allowed to react for another $2 \mathrm{~h}$ at $110^{\circ} \mathrm{C}$ and then cooled to room temperature and subjected to column chromatography over silica gel using hexane/EtOAc (5:1) as eluent to afford the desired (4-chlorophenyl)(2-(aryl)-2H-thiochromen-3-yl)-methanones 15b,c.

\section{(4-Chlorophenyl)(2-(4-(trifluoromethyl)phenyl)-2H-thiochromen-3-yl)methanone (15b)}

Following the general procedure described above, starting from 4-(trifluoromethyl)-benzaldehyde (175 mg, $1 \mathrm{mmol})$ the desired $15 \mathrm{~b}$ was obtained $(200 \mathrm{mg}, 46 \%)$ as a yellow solid m.p.: $105-106{ }^{\circ} \mathrm{C}$. ${ }^{1} \mathrm{H}-\mathrm{NMR}\left(400 \mathrm{MHz}, \mathrm{CDCl}_{3}\right) \delta 7.66(\mathrm{~d}, J=8.6 \mathrm{~Hz}, 2 \mathrm{H}), 7.47(\mathrm{~d}, J=8.5 \mathrm{~Hz}, 4 \mathrm{H}), 7.43(\mathrm{~s}, 1 \mathrm{H}), 7.37(\mathrm{~d}$, $J=8.2 \mathrm{~Hz}, 2 \mathrm{H}), 7.28(\mathrm{t}, J=7.5 \mathrm{~Hz}, 3 \mathrm{H}), 7.18(\mathrm{ddd}, J=7.2,5.3,3.7 \mathrm{~Hz}, 1 \mathrm{H}), 5.43(\mathrm{~s}, 1 \mathrm{H}) .{ }^{13} \mathrm{C}-\mathrm{NMR}$ $\left(75 \mathrm{MHz}, \mathrm{CDCl}_{3}\right) \delta 194.4,145.6,141.0,138.7,136.1,132.33,132.26,131.7,131.2,130.8,130.2,129.9$ (q, $J=32.7 \mathrm{~Hz}), 129.0,127.9,127.0,126.3,125.8(\mathrm{q}, J=3.9 \mathrm{~Hz}), 123.8(\mathrm{q}, J=270.4 \mathrm{~Hz}), 40.0$. IR v: 2952, 1612, 1585, 1323, 1114. HRMS-ESI $(\mathrm{m} / \mathrm{z})$ : calcd. for $\mathrm{C}_{23} \mathrm{H}_{14} \mathrm{ClF}_{3} \mathrm{OS}[\mathrm{M}+\mathrm{Na}]^{+} 453.0298$, found: 453.0304 .

\section{(4-Chlorophenyl)(2-(4-nitrophenyl)-2H-thiochromen-3-yl)methanone (15c)}

Following the general procedure described above, starting from 4-nitrobenzaldehyde (152 $\mathrm{mg}$, $1 \mathrm{mmol})$ the desired $15 \mathrm{c}(180 \mathrm{mg}, 45 \%)$ was obtained as a yellow solid, m.p.: $93-94{ }^{\circ} \mathrm{C} .{ }^{1} \mathrm{H}-\mathrm{NMR}$ $\left(400 \mathrm{MHz}, \mathrm{CDCl}_{3}\right) \delta 8.07(\mathrm{~d}, J=8.7 \mathrm{~Hz}, 2 \mathrm{H}), 7.66(\mathrm{~d}, J=8.4 \mathrm{~Hz}, 2 \mathrm{H}), 7.52-7.38(\mathrm{~m}, 5 \mathrm{H}), 7.34-7.25(\mathrm{~m}$, 3H), 7.22-7.16 (m, 1H), $5.42(\mathrm{~s}, 1 \mathrm{H}) .{ }^{13} \mathrm{C} \mathrm{NMR}\left(75 \mathrm{MHz}, \mathrm{CDCl}_{3}\right) \delta{ }^{13} \mathrm{C}-\mathrm{NMR}\left(101 \mathrm{MHz}, \mathrm{CDCl}_{3}\right) \delta 194.3$, 148.9, 147.4, 141.3, 138.9, 136.3, 135.9, 132.0, 131.9, 131.4, 130.8, 130.2, 129.1, 128.1, 127.6, 126.6, 124.2, 40.1. IR v: $3026,2849,1656,1607,1585,1515,1338,821$. HRMS-ESI ( $m / z)$ : calcd. for $\mathrm{C}_{22} \mathrm{H}_{14} \mathrm{ClNO}_{3} \mathrm{~S}$ [M $+\mathrm{Na}]^{+}$408.0456, found: 408.0461 .

\subsubsection{General Procedure for the Synthesis of the 4-oxo-thiochromane-2-carboxylic acids 20a-d}

A round bottom flask equipped with a magnetic stirrer was loaded with a mixture of maleic anhydride (1.718 g, $17.5 \mathrm{mmol})$ and a slight excess of thiophenols (19.3 mmol, 1.1 equivalents) in acetonitrile dry and then triethylamine (10 drops) was slowly added. The reaction flask was closed with a glass-stopper and stirred at $50{ }^{\circ} \mathrm{C}$ for $2 \mathrm{~h}$. The reaction was quenched at room temperature, the solvent was removed under reduced pressure, and the black oily residue was cooled at $0{ }^{\circ} \mathrm{C}$ in bath ice, and redissolved with dry DCM, after which a significant excess of $\mathrm{AlCl}_{3}$ was added. The mixture reaction was stirred at room temperature overnight. After the reaction was completed as determined by TLC, the mixture reaction was treated with a cold solution of hydrochloric acid (5\%) and extracted with $\mathrm{CH}_{2} \mathrm{Cl}_{2}(3 \times 25 \mathrm{~mL})$ three times. The combined organic layers were dried over anhydrous $\mathrm{Na}_{2} \mathrm{SO}_{4}$, the residue after solvent evaporation the mixture was filtered through a silica gel column using as mobile phase hexanes/ethyl acetate with $5 \%$ of acetic acid as an additive (80:20 v/v) to give pure compounds $\mathbf{2 0 a}-\mathbf{d}$ in $55-70 \%$ global yield.

\section{4-Oxothiochromane-2-carboxylic acid (20a)}

White solid, m.p.: $=151-152{ }^{\circ} \mathrm{C} .{ }^{1} \mathrm{H}-\mathrm{NMR}\left(300 \mathrm{MHz}, \mathrm{DMSO}_{6}\right) \delta 7.95(\mathrm{dd}, \mathrm{J}=7.9,1.5 \mathrm{~Hz}, 1 \mathrm{H})$, $7.49(\mathrm{td}, \mathrm{J}=7.6,1.5 \mathrm{~Hz}, 1 \mathrm{H}), 7.35(\mathrm{~d}, \mathrm{~J}=7.8 \mathrm{~Hz}, 1 \mathrm{H}), 7.25(\mathrm{t}, \mathrm{J}=7.6 \mathrm{~Hz}, 1 \mathrm{H}), 4.39(\mathrm{dd}, \mathrm{J}=6.1,4.3 \mathrm{~Hz}, 1 \mathrm{H})$, 3.19-2.97 (m, 2H). ${ }^{13} \mathrm{C}-\mathrm{NMR}(75 \mathrm{MHz}, \mathrm{DMSO}) \delta 192.63,172.14,138.99,134.25,130.52,128.37,127.82$, 125.94, 41.71, 41.26. IR $v\left(\mathrm{~cm}^{-1}\right)=2918.37,1695.44,1681.12,881.15,768.35$. HRMS-ESI $(\mathrm{m} / \mathrm{z})$ : calcd. for $\mathrm{C}_{10} \mathrm{H}_{8} \mathrm{O}_{3} \mathrm{~S}[\mathrm{M}+\mathrm{H}]^{+}$209.0267, found 209.0282 .

\section{6-Fluoro-4-oxo-thiochromane-2-carboxylic acid (20b)}

White solid, m.p.: $=135-137^{\circ} \mathrm{C} .{ }^{1} \mathrm{H}-\mathrm{NMR}\left(300 \mathrm{MHz}, \mathrm{DMSO}-\mathrm{d}_{6}\right) \delta 7.66(\mathrm{~d}, \mathrm{~J}=11.0 \mathrm{~Hz}, 1 \mathrm{H}), 7.44(\mathrm{~s}$, $1 \mathrm{H}), 7.23(\mathrm{t}, \mathrm{J}=8.8 \mathrm{~Hz}, 1 \mathrm{H}), 4.40(\mathrm{t}, \mathrm{J}=5.1 \mathrm{~Hz}, 1 \mathrm{H}), 3.10(\mathrm{t}, \mathrm{J}=4.9 \mathrm{~Hz}, 2 \mathrm{H}) \cdot{ }^{13} \mathrm{C}-\mathrm{NMR}(75 \mathrm{MHz}, \mathrm{DMSO}) \delta$ $191.92,172.33,162.10,158.86,134.47,127.97,122.07,116.53,114.27,41.62,40.92 . \mathrm{IR} v\left(\mathrm{~cm}^{-1}\right)=3498.15$, 2895.35, 1723.95, 1684.65, 805.21, 238.57. HRMS-ESI $(\mathrm{m} / \mathrm{z})$ : calcd. for $\mathrm{C}_{10} \mathrm{H}_{7} \mathrm{O}_{3} \mathrm{FS}[\mathrm{M}+\mathrm{H}]^{+} 227.0173$, found 227.0173 . 
6-Methoxy-4-oxo-thiochromane-2-carboxylic acid (20c)

White solid, m.p.: $=165-166{ }^{\circ} \mathrm{C}^{1} \mathrm{H}-\mathrm{NMR}\left(300 \mathrm{MHz}, \mathrm{DMSO}^{\mathrm{d}} \mathrm{d}_{6}\right) \delta 7.45(\mathrm{~d}, \mathrm{~J}=2.8 \mathrm{~Hz}, 1 \mathrm{H}), 7.27$ $(\mathrm{d}, \mathrm{J}=8.7 \mathrm{~Hz}, 1 \mathrm{H}), 7.12(\mathrm{~d}, \mathrm{~J}=8.7 \mathrm{~Hz}, 1 \mathrm{H}), 3.77(\mathrm{~s}, 3 \mathrm{H}), 3.15-2.96(\mathrm{~m}, 2 \mathrm{H}) .{ }^{13} \mathrm{C}-\mathrm{NMR}(75 \mathrm{MHz}$, DMSO) $\delta 192.60,172.21,157.64,131.43,129.80,129.28,122.05,111.46,55.83,41.70,40.44$. IR $v$ $\left(\mathrm{cm}^{-1}\right)=2888.72,1714.93,1626.73,881.75,807.73$. HRMS-ESI $(\mathrm{m} / \mathrm{z})$ : calcd. for $\mathrm{C}_{11} \mathrm{H}_{10} \mathrm{O}_{4} \mathrm{~S}[\mathrm{M}+\mathrm{H}]^{+}$ 239.0373, found 239.0387.

\section{7-Methoxy-4-oxo-thiochromane-2-carboxylic acid (20d)}

White solid, m.p.: $=162-164{ }^{\circ} \mathrm{C}^{1} \mathrm{H}-\mathrm{NMR}\left(300 \mathrm{MHz}\right.$, acetone- $\left.\mathrm{d}_{6}\right) \delta 7.99(\mathrm{~d}, \mathrm{~J}=8.6 \mathrm{~Hz}, 1 \mathrm{H}), 6.83(\mathrm{~d}$, $\mathrm{J}=2.4 \mathrm{~Hz}, 1 \mathrm{H}), 6.83-6.78(\mathrm{~m}, 1 \mathrm{H}), 4.36(\mathrm{dd}, \mathrm{J}=6.4,4.7 \mathrm{~Hz}, 1 \mathrm{H}), 3.88(\mathrm{~s}, 3 \mathrm{H}), 3.08(\mathrm{dd}, \mathrm{J}=5.6,3.5 \mathrm{~Hz}, 2 \mathrm{H})$. ${ }^{13} \mathrm{C}$ NMR $\left(75 \mathrm{MHz}\right.$, acetone- $\left.\mathrm{d}_{6}\right) \delta 190.56,170.91,163.51,141.17,130.44,124.13,112.67,110.55,55.29$, 41.97, 40.89. IR $v\left(\mathrm{~cm}^{-1}\right)=3419.98,2906.14,1698.81,1671.88,870.22,824.56$. HRMS-ESI $(\mathrm{m} / \mathrm{z})$ : calcd. for $\mathrm{C}_{11} \mathrm{H}_{10} \mathrm{O}_{4} \mathrm{~S}[\mathrm{M}+\mathrm{H}]^{+}$239.0373, found $=239.0375$.

4.1.6. General Procedure for the Synthesis of the Esters from 4-oxo-thiochromane-2-carboxylic acids 22a-d

A mixture of 4-oxo-thiochromane-2-carboxylic acid (20a, $100 \mathrm{mg}, 0.48 \mathrm{mmol}$ ), $N, N^{\prime}$ dicyclohexylcarbodiimide (DCC, $150 \mathrm{mg}$ ) and small amount of 4-dimethylaminopyridine (DMAP) were dissolved in acetonitrile $(10 \mathrm{~mL})$ and heated under microwave irradiation at $70{ }^{\circ} \mathrm{C}$ for $20 \mathrm{~min}$, then 1.3 equivalents of the corresponding aliphatic alcohol were added. After that the reaction vial was sealed and heated to $70{ }^{\circ} \mathrm{C}$ for $40 \mathrm{~min}$. When the reaction was completed as determined by TLC, the reaction mixture was diluted with ethyl acetate and washed with brine $(2 \times 20 \mathrm{~mL})$. The combined organic layers were dried over anhydrous $\mathrm{Na}_{2} \mathrm{SO}_{4}$, and the residue after solvent evaporation was purified by flash chromatography using hexanes/ethyl acetate $(80: 20 v / v)$ to give $22 \mathbf{a}-\mathbf{d}$ in $65-80 \%$ yield.

Ethyl 4-oxo-thiochromane-2-carboxylate (22a)

Yellowish oil. ${ }^{1} \mathrm{H}-\mathrm{NMR}\left(300 \mathrm{MHz}, \mathrm{CDCl}_{3}\right) \delta 8.14(\mathrm{~d}, J=9.2 \mathrm{~Hz}, 1 \mathrm{H}), 7.42(\mathrm{~d}, J=8.7 \mathrm{~Hz}, 1 \mathrm{H})$, 7.31-7.19 (m, 2H), 4.27-4.12 (m, 3H), $3.21(\mathrm{~d}, J=6.5 \mathrm{~Hz}, 1 \mathrm{H}), 1.25(\mathrm{t}, J=7.1 \mathrm{~Hz}, 3 \mathrm{H}) .{ }^{13} \mathrm{C}-\mathrm{NMR}(75 \mathrm{MHz}$, $\left.\mathrm{CDCl}_{3}\right) \delta 192.24,169.85,138.45,133.71,130.45,128.85,127.37,126.22,125.77,77.55,77.13,76.70,62.27$, 42.34, 41.34, 13.97. IR $\vee\left(\mathrm{cm}^{-1}\right)=2981.39,1731.29,1684.23$, 761.18. HRMS-ESI $(\mathrm{m} / \mathrm{z})$ : calcd. for $\mathrm{C}_{12} \mathrm{H}_{12} \mathrm{O}_{3} \mathrm{~S}[\mathrm{M}+\mathrm{H}]^{+}$237.0580, found 237.0592.

Butyl 4-oxo-thiochromane-2-carboxylate (22b)

Yellowish oil. ${ }^{1} \mathrm{H}-\mathrm{NMR}\left(300 \mathrm{MHz}, \mathrm{CDCl}_{3}\right) \delta 8.14(\mathrm{dd}, J=7.9,1.6 \mathrm{~Hz}, 1 \mathrm{H}), 7.43(\mathrm{ddd}, J=8.0,7.2$, $1.6 \mathrm{~Hz}, 1 \mathrm{H}), 7.34-7.18(\mathrm{~m}, 2 \mathrm{H}), 4.24-4.04(\mathrm{~m}, 3 \mathrm{H}), 3.21(\mathrm{dd}, J=5.6,1.6 \mathrm{~Hz}, 2 \mathrm{H}), 1.66-1.45(\mathrm{~m}, 2 \mathrm{H})$, $1.40-1.22(\mathrm{~m}, 2 \mathrm{H}), 0.90(\mathrm{t}, J=7.3 \mathrm{~Hz}, 3 \mathrm{H}) .{ }^{13} \mathrm{C}-\mathrm{NMR}\left(75 \mathrm{MHz}, \mathrm{CDCl}_{3}\right) \delta 192.18,169.94,141.93,138.49$, $137.47,133.68,132.32,130.47,129.25,129.14,128.84,128.69,128.30,127.36,125.74,77.55,77.12,76.70$, $67.08,66.06,42.46,41.34,30.38,19.16,18.94,13.71,13.63 . \mathrm{IR} v\left(\mathrm{~cm}^{-1}\right)=2960.28,2933.24,1731.63,1683.60$, 758.76. HRMS-ESI $(\mathrm{m} / \mathrm{z})$ : calcd. for $\mathrm{C}_{14} \mathrm{H}_{16} \mathrm{O}_{3} \mathrm{~S}[\mathrm{M}+\mathrm{Na}]^{+}$287.0712, found 287.0709.

Hexyl 4-oxo-thiochromane-2-carboxylate (22c)

Yellowish oil. ${ }^{1} \mathrm{H}-\mathrm{NMR}\left(300 \mathrm{MHz}, \mathrm{CDCl}_{3}\right) \delta 8.13(\mathrm{~d}, J=7.9 \mathrm{~Hz}, 1 \mathrm{H}), 7.41(\mathrm{t}, J=7.5 \mathrm{~Hz}, 1 \mathrm{H})$, 7.28-7.16 (m, 2H), $4.14(\mathrm{q}, J=6.5,5.8 \mathrm{~Hz}, 3 \mathrm{H}), 3.20(\mathrm{~d}, J=5.8 \mathrm{~Hz}, 2 \mathrm{H}), 1.57(\mathrm{p}, \mathrm{J}=6.4 \mathrm{~Hz}, 3 \mathrm{H}), 1.25$ $(\mathrm{s}, 6 \mathrm{H}), 0.88(\mathrm{t}, \mathrm{J}=6.0 \mathrm{~Hz}, 3 \mathrm{H}) .{ }^{13} \mathrm{C}-\mathrm{NMR}\left(75 \mathrm{MHz}, \mathrm{CDCl}_{3}\right) \delta 192.14,169.95,138.48,133.67,130.45$, $128.81,127.33,125.72,66.33,42.42,41.30,31.31,28.34,25.35,22.49,14.01$. IR $v\left(\mathrm{~cm}^{-1}\right)=3056.06,2959.62$, $1730.43,1684.96,738.80$. HRMS-ESI $(m / z)$ : calcd. for $\mathrm{C}_{16} \mathrm{H}_{20} \mathrm{O}_{3} \mathrm{~S}[\mathrm{M}+\mathrm{Na}]^{+} 315.1025$, found 315.1005 
Decyl 4-oxo-thiochromane-2-carboxylate (22d)

Yellowish oil. ${ }^{1} \mathrm{H}-\mathrm{NMR}\left(300 \mathrm{MHz}, \mathrm{CDCl}_{3}\right) \delta 8.14(\mathrm{dd}, J=7.9,1.5 \mathrm{~Hz}, 1 \mathrm{H}), 7.43(\mathrm{td}, J=7.7,1.6 \mathrm{~Hz}$, $1 \mathrm{H}), 7.31-7.20(\mathrm{~m}, 2 \mathrm{H}), 4.19-4.11(\mathrm{~m}, 3 \mathrm{H}), 3.25-3.18(\mathrm{~m}, 2 \mathrm{H}), 1.58(\mathrm{~d}, J=6.6 \mathrm{~Hz}, 2 \mathrm{H}), 1.27(\mathrm{~d}, J=5.7 \mathrm{~Hz}$, 16H), 0.95-0.87 (m, 3H) ${ }^{13} \mathrm{C}-\mathrm{NMR}\left(75 \mathrm{MHz}, \mathrm{CDCl}_{3}\right) \delta 192.15,169.94,138.50,133.67,130.47,128.85$, 127.34, 125.73, 77.53, 77.11, 76.68, 66.36, 42.45, 41.32, 31.91, 29.53, 29.48, 29.33, 29.17, 28.40, 25.70, 22.71, 14.16. IR $v\left(\mathrm{~cm}^{-1}\right)=2954.83,2925.62,1734.22,1686.36,759.28$. HRMS-ESI $(\mathrm{m} / \mathrm{z})$ : calcd. for $\mathrm{C}_{20} \mathrm{H}_{28} \mathrm{O}_{3} \mathrm{~S}$ $[\mathrm{M}+\mathrm{H}]^{+} 349.1832$, found 349.1864

\subsubsection{General Procedure for the Synthesis of the -4-oxo-thiochromane-2-carboxamides 24a-c}

To a mixture of 4-oxo-thiochromane-2-carboxylic acid (20a, $1.0 \mathrm{~g}, 4.8 \mathrm{mmol})$ in anhydrous DCM $(5 \mathrm{~mL})$, at $0{ }^{\circ} \mathrm{C}$ was added a small amount of DMF, followed by oxalyl chloride $(10.0 \mathrm{mmol})$. Once the effervescence stopped, the solution was quenched to room temperature for $2 \mathrm{~h}$. FT-IR analyses determined that the acid chloride was formed as a brownish oil since Fermi resonance was observed. Next, a solution of amine $(10.0 \mathrm{mmol})$ in $\mathrm{DCM}(5 \mathrm{~mL})$ and $\mathrm{NaOH}(2.0 \mathrm{M}, 5 \mathrm{~mL})$ was slowly added to the initial mixture, under Schotten-Baumann conditions and stirred to room temperature overnight to give to corresponding amides. When the reaction was completed as determined by TLC, the reaction mixture was diluted with ethyl acetate and washed with brine $(2 \times 20 \mathrm{~mL})$. The combined organic layers were dried over anhydrous $\mathrm{Na}_{2} \mathrm{SO}_{4}$, and the residue after solvent evaporation was purified by flash chromatography using hexanes/ethyl acetate $(80: 20 v / v)$ as eluent to give pure molecules $3 \mathbf{i}-\mathbf{k}$ in $30-35 \%$ yield.

\section{N-hexyl-4-oxo-thiochromane-2-carboxamide (24a)}

White solid. m.p.: $128-129^{\circ} \mathrm{C} .{ }^{1} \mathrm{H}-\mathrm{NMR}\left(300 \mathrm{MHz}, \mathrm{CDCl}_{3}\right) \delta 8.13(\mathrm{~d}, J=7.9 \mathrm{~Hz}, 1 \mathrm{H}), 7.44(\mathrm{t}$, $\mathrm{J}=7.6 \mathrm{~Hz}, 1 \mathrm{H}), 7.33-7.22(\mathrm{~m}, 2 \mathrm{H}), 6.56(\mathrm{t}, \mathrm{J}=5.9 \mathrm{~Hz}, 1 \mathrm{H}), 4.05(\mathrm{t}, J=5.4 \mathrm{~Hz}, 1 \mathrm{H}), 3.48(\mathrm{dd}, J=16.8,6.5 \mathrm{~Hz}$, $1 \mathrm{H}), 3.36-3.05(\mathrm{~m}, 3 \mathrm{H}), 1.41(\mathrm{p}, J=7.1 \mathrm{~Hz}, 2 \mathrm{H}), 1.23(\mathrm{td}, J=12.1,10.4,5.6 \mathrm{~Hz}, 6 \mathrm{H}), 0.87(\mathrm{t}, J=6.6 \mathrm{~Hz}$, 3H). ${ }^{13} \mathrm{C}-\mathrm{NMR}\left(75 \mathrm{MHz}, \mathrm{CDCl}_{3}\right) \delta 192.52,168.50,138.06,133.66,131.04,129.19,127.47,126.00,77.53$, 77.11, 76.68, 43.57, 41.75, 40.07, 31.39, 29.29, 26.31, 22.52, 14.04. IR $v\left(\mathrm{~cm}^{-1}\right)=3331.59,2926.30,2859.39$, 1658.69, 755.77. HRMS-ESI ( $m / z)$ : calcd. for $\mathrm{C}_{16} \mathrm{H}_{21} \mathrm{NO}_{2} \mathrm{~S}[\mathrm{M}+\mathrm{H}]^{+}$292.1366, found 292.1393.

N-dodecyl-4-oxo-thiochromane-2-carboxamide (24b)

White solid, m.p.: $125-127{ }^{\circ} \mathrm{C} .{ }^{1} \mathrm{H}-\mathrm{NMR}\left(300 \mathrm{MHz}, \mathrm{CDCl}_{3}\right) \delta 8.14(\mathrm{~d}, J=7.9 \mathrm{~Hz}, 1 \mathrm{H}), 7.44(\mathrm{t}$, $J=7.6 \mathrm{~Hz}, 1 \mathrm{H}), 7.34-7.22(\mathrm{~m}, 2 \mathrm{H}), 6.50(\mathrm{~d}, J=7.2 \mathrm{~Hz}, 1 \mathrm{H}), 4.05(\mathrm{t}, J=5.4 \mathrm{~Hz}, 1 \mathrm{H}), 3.49(\mathrm{dd}, J=16.7$, $6.5 \mathrm{~Hz}, 1 \mathrm{H}), 3.37-3.08(\mathrm{~m}, 3 \mathrm{H}), 1.49-1.14(\mathrm{~m}, 19 \mathrm{H}), 0.97-0.86(\mathrm{~m}, 3 \mathrm{H}) .{ }^{13} \mathrm{C}-\mathrm{NMR}\left(75 \mathrm{MHz}, \mathrm{CDCl}_{3}\right) \delta$ 192.44, 168.41, 138.00, 133.66, 131.08, 129.24, 127.48, 126.04, 77.52, 77.09, 76.67, 43.59, 41.75, 40.09, 31.96, $29.68,29.68,29.61,29.53,29.40,29.40,29.34,29.24,29.24,26.66,22.74,14.18 . \quad \mathrm{IR} \vee\left(\mathrm{cm}^{-1}\right)=3365.75$, 2979.88, 2913.42, 1686.63, 779.84. HRMS-ESI $(m / z)$ : calcd. for $\mathrm{C}_{22} \mathrm{H}_{33} \mathrm{NO}_{2} \mathrm{~S}[\mathrm{M}+\mathrm{H}]^{+} 376.2305$, found 376.2314 .

4-Oxo-N-(o-tolyl)thiochromane-2-carboxamide (24c)

Yellowish solid, m.p.: $144-146^{\circ} \mathrm{C} .{ }^{1} \mathrm{H}-\mathrm{NMR}\left(300 \mathrm{MHz}, \mathrm{CDCl}_{3}\right) \delta 7.61(\mathrm{~s}, 1 \mathrm{H}), 7.40(\mathrm{~d}, J=7.8 \mathrm{~Hz}$, $1 \mathrm{H}), 6.95(\mathrm{~d}, J=7.9 \mathrm{~Hz}, 1 \mathrm{H}), 6.71(\mathrm{t}, J=7.7 \mathrm{~Hz}, 1 \mathrm{H}), 6.64-6.36(\mathrm{~m}, 5 \mathrm{H}), 6.33(\mathrm{~d}, J=7.3 \mathrm{~Hz}, 1 \mathrm{H}), 3.48(\mathrm{~d}$, $J=5.5 \mathrm{~Hz}, 1 \mathrm{H}), 2.88(\mathrm{dd}, J=17.1,4.9 \mathrm{~Hz}, 1 \mathrm{H}), 2.45(\mathrm{dd}, J=16.9,4.0 \mathrm{~Hz}, 1 \mathrm{H}), 1.33(\mathrm{~s}, 3 \mathrm{H}) .{ }^{13} \mathrm{C}-\mathrm{NMR}$ (75 MHz, CDCl3) $\delta$ 192.00, 166.95, 137.28, 134.97, 133.87, 131.26, 130.54, 129.57, 129.51, 129.41, 127.64, 126.82, 126.64, 126.46, 125.71, 122.97, 77.54, 77.11, 76.69, 44.11, 41.51, 17.43. IR $v\left(\mathrm{~cm}^{-1}\right)=3261.48$, 1673.35, 1650.48, 748.51. HRMS-ESI $(m / z)$ : calcd. for $\mathrm{C}_{17} \mathrm{H}_{15} \mathrm{NO}_{2} \mathrm{~S}[\mathrm{M}+\mathrm{H}]^{+} 298.0896$, found 298.0919

\subsubsection{General Procedure for the Synthesis of Thiochromane Hydrazones}

Ethyl 4-oxo-thiochromane-2-carboxylate (22a, $500 \mathrm{mg}$ ) was dissolved in anhydrous methanol $(25 \mathrm{~mL})$. The mixture was heated at reflux for $12 \mathrm{~h}$ with the corresponding hydrazide $(1.6 \mathrm{mmol})$ 
and glacial acetic acid $(100 \mu \mathrm{L})$. When the reaction was completed, as determined by the resulting precipitate, the acyl hydrazones were collected by filtration and washed with methanol to give pure products $26 \mathbf{a}-\mathbf{c}$ as white solids in $90-98 \%$ yield.

Ethyl 4-(2-benzoylhydrazineylidene)thiochromane-2-carboxylate (26a)

White solid m.p.: 170-171 ${ }^{\circ} \mathrm{C} .{ }^{1} \mathrm{H}-\mathrm{NMR}\left(300 \mathrm{MHz}, \mathrm{DMSO}-\mathrm{d}_{6}\right) \delta 11.20(\mathrm{~s}, 1 \mathrm{H}), 8.77(\mathrm{~d}, J=5.3 \mathrm{~Hz}$, $3 \mathrm{H}), 8.15(\mathrm{~d}, J=7.9 \mathrm{~Hz}, 1 \mathrm{H}), 7.80(\mathrm{~d}, J=5.1 \mathrm{~Hz}, 2 \mathrm{H}), 7.29(\mathrm{tt}, J=15.7,7.4 \mathrm{~Hz}, 4 \mathrm{H}), 4.38(\mathrm{dd}, J=6.7$, $4.5 \mathrm{~Hz}, 1 \mathrm{H}), 4.08(\mathrm{q}, J=7.1 \mathrm{~Hz}, 3 \mathrm{H}), 3.22(\mathrm{dd}, J=17.5,4.6 \mathrm{~Hz}, 1 \mathrm{H}), 1.13(\mathrm{q}, J=8.2,7.1 \mathrm{~Hz}, 4 \mathrm{H}) .{ }^{13} \mathrm{C}-\mathrm{NMR}$ (75 MHz, DMSO) $\delta 170.41,163.11,152.94,150.62,141.41,133.54,131.33,130.66,128.21,127.05,126.27$, $122.39,61.85,40.72,40.58,40.44,40.17,39.89,39.61,39.34,39.05,30.28,14.32$. IR $v\left(\mathrm{~cm}^{-1}\right)=3173.40$, $2978.57,1718.42,1652.27,754.99,734.77$. HRMS-ESI $(\mathrm{m} / \mathrm{z})$ : calcd. for $\mathrm{C}_{19} \mathrm{H}_{18} \mathrm{~N}_{2} \mathrm{O}_{3} \mathrm{~S}[\mathrm{M}+\mathrm{H}]^{+} 355.1111$, found 355.1135 .

\section{Ethyl 4-(2-isonicotinoylhydrazineylidene)thiochromane-2-carboxylate (26b)}

White solid, m.p.: 190-192 ${ }^{\circ} \mathrm{C} .{ }^{1} \mathrm{H}-\mathrm{NMR}\left(300 \mathrm{MHz}, \mathrm{DMSO}-\mathrm{d}_{6}\right) \delta 10.97(\mathrm{~s}, 1 \mathrm{H}), 8.14(\mathrm{~s}, 1 \mathrm{H}), 7.88$ $(\mathrm{d}, J=7.4 \mathrm{~Hz}, 2 \mathrm{H}), 7.55(\mathrm{dt}, J=14.8,7.2 \mathrm{~Hz}, 3 \mathrm{H}), 7.25(\mathrm{~d}, J=18.9 \mathrm{~Hz}, 3 \mathrm{H}), 4.38(\mathrm{t}, J=5.5 \mathrm{~Hz}, 1 \mathrm{H})$, $4.08(\mathrm{q}, J=7.2 \mathrm{~Hz}, 2 \mathrm{H}), 1.12(\mathrm{t}, J=7.1 \mathrm{~Hz}, 3 \mathrm{H}) .{ }^{13} \mathrm{C}-\mathrm{NMR}(75 \mathrm{MHz}, \mathrm{DMSO}) \delta 170.43,164.52,134.38$, 134.37, 133.29, 132.09, 131.61, 130.34, 128.79, 128.46, 128.18, 126.92, 126.21, 61.81, 30.11, 14.33. IR v $\left(\mathrm{cm}^{-1}\right)=3145.28,2947.51,1717.64,1651.30,759.40,708.68$. HRMS-ESI $(\mathrm{m} / \mathrm{z})$ : calcd. for $\mathrm{C}_{18} \mathrm{H}_{17} \mathrm{~N}_{3} \mathrm{O}_{3} \mathrm{~S}$ $[\mathrm{M}+\mathrm{H}]^{+}$356.1063, found 356.1096.

\section{4-(2-Carbamoylhydrazineylidene)thiochromane-2-carboxylic acid (26c)}

White solid, m.p.: $238{ }^{\circ} \mathrm{C} .{ }^{1} \mathrm{H}-\mathrm{NMR}\left(300 \mathrm{MHz}, \mathrm{DMSO}-\mathrm{d}_{6}\right) \delta 9.44(\mathrm{~s}, 1 \mathrm{H}), 8.73(\mathrm{~s}, 1 \mathrm{H}), 8.23(\mathrm{~d}$, $J=7.8 \mathrm{~Hz}, 1 \mathrm{H}), 7.21(\mathrm{~d}, J=4.0 \mathrm{~Hz}, 2 \mathrm{H}), 7.14(\mathrm{dq}, J=8.3,4.3 \mathrm{~Hz}, 1 \mathrm{H}), 6.58(\mathrm{~s}, 2 \mathrm{H}), 4.18(\mathrm{dd}, J=6.8$, $4.7 \mathrm{~Hz}, 1 \mathrm{H}), 3.12(\mathrm{dd}, J=17.6,7.0 \mathrm{~Hz}, 1 \mathrm{H}), 2.99(\mathrm{dd}, J=17.6,4.9 \mathrm{~Hz}, 1 \mathrm{H}) .{ }^{13} \mathrm{C}-\mathrm{NMR}(75 \mathrm{MHz}, \mathrm{DMSO}-\mathrm{d} 6)$ $\delta 171.99,157.60,141.08,132.46,132.16,129.08,128.17,126.80,126.10,41.16,30.31 . \mathrm{IR} v\left(\mathrm{~cm}^{-1}\right)=3469.94$, $3237.11,2906.14,1713.23,1645.36,757.97,736.96$. HRMS-ESI $(m / z)$ : calcd. for $\mathrm{C}_{11} \mathrm{H}_{11} \mathrm{~N}_{3} \mathrm{O}_{3} \mathrm{~S}[\mathrm{M}+\mathrm{H}]^{+}$ 266.0594, found 266.0595.

\subsection{Resolution of the racemic acids and derivatives}

4-Oxothiochromane-2-carboxylic acid (22a, $1.0 \mathrm{~g}$ ) dissolved in Tetrahydrofuran (THF)/water (5 mL, ratio $4: 1$ ), was mixed with brucine (2 equivalents). The reaction mixture was overnight stirred at room temperature. The solvent was evaporated under reduced pressure, and the resulting solid was re-dissolved in hot ethyl acetate. A crystal phase was generated which was filtered off resulting in two new fractions (solid and liquid diastereomers). Both fractions were subjected to acid extraction (10\% $\mathrm{HCl})$ The resultant mixture was quenched with saturated brine $(20 \mathrm{~mL})$ and was extracted with hot ethyl acetate $(10 \mathrm{~mL})$ three-times. The organic layers were combined, washed with brine, and dried with anhydrous $\mathrm{Na}_{2} \mathrm{SO}_{4}$. After concentrating in vacuo the resultant residue was purified by flash chromatography (ethyl acetate: $n$-hexane $=1: 10$ ) to give pure $(+)$-20a in 10\% yield (specific rotation $\left.[\alpha]_{\mathrm{D}}^{25}=35.6\right)$ as well $(-)-20 \mathrm{a}$ in $45 \%$ yield $\left([\alpha]_{\mathrm{D}}^{25}=-10.8\right)$. The enantiomerically enriched acids mentioned above, (+)-20a and (-)-20a, were esterified according with general methodology before described in the general procedure for the synthesis of the esters from 4-oxothiochromane-2-carboxylic acids to give compounds $(+)-\mathbf{2 2} \mathbf{b}\left(9 \%\right.$ yield, specific rotation $\left.[\alpha]_{\mathrm{D}}^{25}=32.4\right)$ and $(-)-\mathbf{2 2} \mathbf{b}(85 \%$ yield, specific rotation $\left.[\alpha]_{\mathrm{D}}^{25}=-8.3\right)$.

\subsection{Biological Activity}

\subsubsection{Cytotoxic Activity}

Cytotoxicity of the compounds was evaluated on human monocytes (U-937 ATCC CRL-1593.2) in an exponential growth phase and adjusted at $1 \times 105$ cells $/ \mathrm{mL}$ in RPMI-1640 enriched with 10\% 
fetal bovine serum (FBS). One hundred microliters of cell suspension were dispensed in each well of a 96-wells microplate, and then $100 \mu \mathrm{L}$ of 200-50-12.5 and $3.125 \mu \mathrm{g} / \mathrm{mL}$ concentration of each compound or standard drug (amphotericin B) were added dissolved in PBS with 0.5\% DMSO. Cell exposed to compounds or standard drugs were incubated $72 \mathrm{~h}$ at $37^{\circ} \mathrm{C}$ and $5 \%$ of $\mathrm{CO}_{2}$. Cytotoxic activity of each compound was determined according to the effect on the cell viability by the MTT microenzymatic method in which 3-(4,5-dimethylthiazol-2-yl)-2,5-diphenyltetrazolium bromide is reduced to a purple formazan product by mitochondrial enzyme succinate dehydrogenase. Thus, $10 \mu \mathrm{L} /$ well of MTT solution $(5 \mathrm{mg} / \mathrm{mL})$ was added to each well of exposed and unexposed cells, and plates were incubated at $37^{\circ} \mathrm{C}, 5 \% \mathrm{CO}_{2}$ during $3 \mathrm{~h}$. The reaction was stopped by adding $100 \mu \mathrm{L} /$ well of isopropanol with $50 \%$ and $10 \%$ of SDS (sodium dodecyl sulfate). The concentration of formazan was determined spectrophotometrically at $570 \mathrm{~nm}$ (Varioskan, Thermo, Waltham, MA, USA) and intensity of color (absorbance) was registered as O.D. Cells exposed to control drug (amphotericin B) were used as control for toxicity (positive control) while cell incubated in the absence of any compound or drug were used as control for viability (negative control). Non-specific absorbance was corrected by subtracting absorbance (O.D) of the blank. Determinations were done by triplicate in at least two independent experiments [24].

\subsubsection{Antileishmanial Activity}

Antileishmanial activity of compounds was determined according to the ability of the compound to reduce the infection by L. panamensis parasites. For this, the antileishmanial activity was tested on intracellular amastigotes of L. panamensis transfected with the green fluorescent protein gene (MHOM/CO/87/UA140-EGFP strain) [22]. Briefly, U-937 human cells at a density of $3 \times 105$ cells/mL in RPMI 1640 and $0.1 \mu \mathrm{g} / \mathrm{mL}$ of PMA (phorbol-12-myristate-13-acetate) were dispensed on 24-wells microplate and then infected with stationary phase growing L. panamensis promastigotes in 15:1 parasites per cell ratio. Plates were incubated at $34{ }^{\circ} \mathrm{C}$ and $5 \% \mathrm{CO}_{2}$ for $3 \mathrm{~h}$, and then cells were washed twice with phosphate buffer solution (PBS) to eliminate not internalized parasites. Fresh RPMI-1640 was added into each well $(1 \mathrm{~mL})$, and plates were incubated again. After $24 \mathrm{~h}$ of infection, the RPMI-1640 medium was replaced by fresh culture medium containing each compound at four serial dilutions $(50,12.5,3.125$ and $0.78 \mu \mathrm{g} / \mathrm{mL})$ and plates were then incubated at $37^{\circ} \mathrm{C}$ and $5 \% \mathrm{CO}_{2}$ during $72 \mathrm{~h}$, then, cells were removed from the bottom plate with $100 \mu \mathrm{L}$ of EDTA/trypsin $(250 \mathrm{mg})$ solution. The cells were centrifuged at $1100 \mathrm{rpm}$ during $10 \mathrm{~min}$ at $4{ }^{\circ} \mathrm{C}$, the supernatant was discarded, and cells were washed with $1 \mathrm{~mL}$ of cold PBS and centrifuged at $1100 \mathrm{rpm}$ for $10 \mathrm{~min}$ at $4{ }^{\circ} \mathrm{C}$. Cells were washed two times employing PBS, as previously, and after the last wash, the supernatant was discarded, and cells were suspended in $500 \mu \mathrm{L}$ of PBS.

Cells were analyzed by flow cytometry employing a flow cytometer (FC 500MPL, Cytomics, Beckman Coulter. Pasadena, CA, USA) reading at $488 \mathrm{~nm}$ (exciting) and $525 \mathrm{~nm}$ (emitting) over an argon laser and counting 10,000 events. Infected cells were determined according to the events for green fluorescence (parasites). All determinations for each compound and standard drug were carried out by triplicate, in two experiments. Infected cells exposed to control drug (amphotericin B) were used as the control for antileishmanial activity (positive control), while infected cells incubated in the absence of any compound or drug were used as another control for infection (negative control). Nonspecific fluorescence was corrected by subtracting the fluorescence of unstained cells. Determinations were done by triplicate in at least two independent experiments [25,26].

\subsubsection{Statistical Analysis}

Cytotoxicity was determined according to viability and mortality percentages obtained for each experimental condition (synthesized compounds, amphotericin B, and culture medium). Results were expressed as the mean lethal concentrations $\left(\mathrm{LC}_{50}\right)$, the concentration necessary to kill $50 \%$ of cells, calculated by the parametric method of linear regression that permits doses-response analysis (Probit analysis) [25]. 
Initially, viability percentages were calculated by Equation (1), where the O.D of control well, corresponds to $100 \%$ of viability:

$$
\% \text { Viability }=\left(\frac{\text { O.D. exposed cells }}{\text { O.D. unexposed cells }}\right) \times 100
$$

Then, the percentage of cell growth inhibition was calculated using Equation (2):

$$
\% \text { Inhibition }=100-(\% \text { Viability })
$$

The toxicity was defined according to $\mathrm{LC}_{50}$ values, using the follow scale: Toxic; $\mathrm{LC}_{50}<100 \mu \mathrm{M}$; moderately toxic; $\mathrm{LC}_{50}>100 \mu \mathrm{M}$ and $<200 \mu \mathrm{M}$ and potentially nontoxic; $\mathrm{LC}_{50}>200 \mu \mathrm{M}$.

The antileishmanial activity was determined according to the reduction of the percentage of fluorescent parasites determined according to the median fluorescence intensity (MFI) obtained for each experimental condition by cytometry. The parasite values for each concentration of compound were calculated by Equation (3), where the \% of parasites in control well, corresponds to $100 \%$ of parasites:

$$
\% \text { Parasites }=\left(\frac{\text { MFI exposed parasites }}{\text { MFI unexposed parasites }}\right) \times 100
$$

Then, the inhibition percentage was calculated with Equation (4):

$$
\% \text { Inhibitors of Parasites }=100-(\% \text { Parasites })
$$

Results of antileishmanial activities were expressed as the median effective concentrations $\left(\mathrm{EC}_{50}\right)$ measured by Probit method. The activity of each compound was established according to $\mathrm{EC}_{50}$ values as: high activity: $\mathrm{EC}_{50}<25 \mu \mathrm{M}$; moderate activity: $\mathrm{EC}_{50}>25 \mu \mathrm{M}$ and $<100 \mu \mathrm{M}$ and low activity: $\mathrm{EC}_{50}>100 \mu \mathrm{M}$.

Author Contributions: Conceptualization, W.Q. and E.V.; methodology, D.L.; M.C.; E.V. and C.O. bioassays, S.R.; writing - review and editing, E.V., F.E.; project administration, W.Q. and E.V. All authors have read and agreed to the published version of the manuscript.

Funding: This research was funded by COLCIENCIAS and Universidad de Antioquia project code 111571249860, contract 061-2016.

Acknowledgments: Authors thank to COLCIENCIAS and Universidad de Antioquia for funding the project. Esteban Vargas thanks COLCIENCIAS for a fellowship in the Program Doctorados Nacionales 567. Cristian Ortíz thanks Universidad de Antioquia for funding the Master program.

Conflicts of Interest: The authors declare no conflict of interest.

\section{References}

1. DNDi. About Leishmaniasis-DNDi. Available online: https://www.dndi.org/diseases-projects/leishmaniasis/ (accessed on 17 April 2018).

2. Emami, S.; Ghanbarimasir, Z. Recent advances of chroman-4-one derivatives: Synthetic approaches and bioactivities. Eur. J. Med. Chem. 2015, 93, 539-563. [CrossRef] [PubMed]

3. Keri, R.S.; Budagumpi, S.; Pai, R.K.; Balakrishna, R.G. Chromones as a privileged scaffold in drug discovery: A review. Eur. J. Med. Chem. 2014, 78, 340-374. [CrossRef] [PubMed]

4. Welsch, M.E.; Snyder, S.A.; Stockwell, B.R. Privileged scaffolds for library design and drug discovery. Curr. Opin. Chem. Biol. 2010, 14, 347-361. [CrossRef] [PubMed]

5. Johnson, A.T.; Wang, L.; Standeven, A.M.; Escobar, M.; Chandraratna, R.A.S. Synthesis and biological activity of high-affinity retinoic acid receptor antagonists. Bioorg. Med. Chem. 1999, 7, 1321-1338. [CrossRef]

6. Lima, L.L.M.; Barreiro, E.J. Bioisosterism: A Useful Strategy for Molecular Modification and Drug Design. Curr. Med. Chem. 2005, 12, 23-49. [CrossRef] 
7. Davies, D.J.; Faust, R.; Garratt, P.J.; Marivingt-Mounir, C.; Kathryn, D.; Teh, M.T.; Sugden, D. Binding affinity and biological activity of oxygen and sulfur isosteres at melatonin receptors as a function of their hydrogen bonding capability. Bioorg. Chem. 2004, 32, 1-12. [CrossRef]

8. Upegui, Y.; Rios, K.; Quiñones, W.; Echeverri, F.; Archbold, R.; Murillo, J.D.; Torres, F.; Escobar, G.; Vélez, I.D.; Robledo, S.M. Chroman-4-one hydrazones derivatives: Synthesis, characterization, and in vitro and in vivo antileishmanial effects. Med. Chem. Res. 2019, 28, 2184-2199. [CrossRef]

9. Siles, R.; Chen, S.-E.; Zhou, M.; Pinney, K.G.; Trawick, M.L. Design, synthesis, and biochemical evaluation of novel cruzain inhibitors with potential application in the treatment of Chagas' disease. Bioorg. Med. Chem. Lett. 2006, 16, 4405-4409. [CrossRef]

10. Song, J.; Jones, L.M.; Kumar, G.D.K.; Conner, E.S.; Bayeh, L.; Chavarria, G.E.; Charlton-Sevcik, A.K.; Chen, S.-E.; Chaplin, D.J.; Trawick, M.L.; et al. Synthesis and Biochemical Evaluation of Thiochromanone Thiosemicarbazone Analogues as Inhibitors of Cathepsin L. ACS Med. Chem. Lett. 2012, 3, 450-453. [CrossRef]

11. Vastag, G.; Apostolov, S.; Matijević, B.; Djaković-Sekulić, T. Structure-interaction relationship study of N -(4-phenylsubstituted) cyanoacetamides by multivariate methods. J. Chemom. 2016, 30, 210-216. [CrossRef]

12. Lavis, L.D. Ester Bonds in Prodrugs. ACS Chem. Biol. 2008, 3, 203-206. [CrossRef] [PubMed]

13. Wang, Q.; Finn, M. 2H-Chromenes from salicylaldehydes by a catalytic petasis reaction. Org. Lett. 2000, 2, 4063-4065. [CrossRef] [PubMed]

14. Lu, D.; Li, Y.; Gong, Y. Organocatalytic Asymmetric Tandem Michael Addition-Hemiacetalization: A Route to Chiral Dihydrocoumarins, Chromanes, and $4 \mathrm{H}$-Chromenes. J. Org. Chem. 2010, 75, 6900-6907. [CrossRef]

15. Meng, X.; Huang, Y.; Zhao, H.; Xie, P.; Ma, J.; Chen, R. PPh3-catalyzed domino reaction: A facile method for the synthesis of chroman derivatives. Org. Lett. 2009, 11, 991-994. [CrossRef] [PubMed]

16. Lanari, D.; Rosati, O.; Curini, M. A solvent-free protocol for the synthesis of 3-formyl-2H-chromenes via domino oxa Michael/aldol reaction. Tetrahedron Lett. 2014, 55, 1752-1755. [CrossRef]

17. Chemburkar, S.R.; Anderson, D.G.; Reddy, R.E. Efficient Method for Synthesis of 2-Acetylbenzo(b)thiophene and Its Derivatives, the Key Synthons for 5-Lipoxygenase Inhibitors. Synth. Commun. 2010, 40, 1887-1894. [CrossRef]

18. Humphrey, R.E.; Hawkins, J.M. Reduction of Aromatic Disulfides with Triphenylphosphine. Anal. Chem. 1964, 36, 1812-1814. [CrossRef]

19. Albericio, F.; Isidro-llobet, A.; Mercedes, A. Review Amino acid protecting. Chem. Rev. 2009, 109, $2455-2504$.

20. Bryan, C.S.; Braunger, J.A.; Lautens, M. Efficient Synthesis of Benzothiophenes by an Unusual Palladium-Catalyzed Vinylic C S Coupling. Angew. Chemie Int. Ed. 2009, 48, 7064-7068. [CrossRef]

21. Dickman, D.A.; Chemburkar, S.; Konopacki, D.B.; Elisseou, E.M. Oxidative Cleavage of Aryl or Alkyl tert-Butyl Sulfides with Dimethyl Sulfoxide/Hydrobromic Acid to Form Symmetrical Aryl or Alkyl Disulfides. Synthesis (Stuttg). 1993, 1993, 573-574. [CrossRef]

22. Pulido, S.A.; Muñoz, D.L.; Restrepo, A.M.; Mesa, C.V.; Alzate, J.F.; Vélez, I.D.; Robledo, S.M. Improvement of the green fluorescent protein reporter system in Leishmania spp. for the in vitro and in vivo screening of antileishmanial drugs. Acta Trop. 2012, 122, 36-45. [CrossRef] [PubMed]

23. Vargas, E.; Echeverri, F.; Upegui, Y.A.; Robledo, S.M.; Quiñones, W. Hydrazone derivatives enhance antileishmanial activity of thiochroman-4-ones. Molecules 2018, 23, 70. [CrossRef] [PubMed]

24. Fleming, F.F.; Yao, L.; Ravikumar, P.C.; Funk, L.; Shook, B.C. Nitrile-Containing Pharmaceuticals: Efficacious Roles of the Nitrile Pharmacophore. J. Med. Chem. 2010, 53, 7902-7917. [CrossRef] [PubMed]

25. Taylor, V.M.; Cedeño, D.L.; Muñoz, D.L.; Jones, M.A.; Lash, T.D.; Young, A.M.; Constantino, M.H.; Esposito, N.; Vélez, I.D.; Robledo, S.M. In vitro and in vivo studies of the utility of dimethyl and diethyl carbaporphyrin ketals in treatment of cutaneous leishmaniasis. Antimicrob. Agents Chemother. 2011, 55, 4755-4764.

26. Finney, D.J. Statistical method in biological assay, 3rd ed.; Charles Griffin \& Company: London, UK, 1978; ISBN 0852642520.

Sample Availability: Samples of the compounds are available from the authors upon request. 